\title{
Efficacy of Proxalutamide in Hospitalized COVID-19 Patients: A Randomized, Double-Blind, Placebo-Controlled, Parallel- Design Clinical Trial
}

Flávio Adsuara Cadegiani, $\mathrm{MD}, \mathrm{PhD}_{1,2}$, Daniel do Nascimento Fonseca, $\mathrm{MD}_{3}$, John McCoy, $\mathrm{PhD}_{2}{ }^{*}$, Ricardo Ariel Zimerman, $\mathrm{MD}_{4}$, Fatima Nadeem Mirza, MD, $\mathrm{MPH}_{5}$, Michael do Nascimento Correia, $\mathrm{MD}_{6}$, Renan Nascimento Barros, $\mathrm{MD}_{7}$, Dirce Costa Onety, $\mathrm{MD}_{3}$, Karla Cristina Petruccelli Israel, $\mathrm{MD}_{8,9}$, Brenda Gomes de Almeida, $\mathrm{MD}_{10}$, Emilyn Oliveira Guerreiro 3 , José Erique Miranda Medeiros 3 , Raquel Neves Nicolau Luiza Fernanda Mendonça Nicolau, 3 , Rafael Xavier Cunha, Maria Fernanda Rodrigues Barroco 3 , Patrícia Souza da Silva, Gabriel de Souza Ferreira, $\mathrm{MD}_{7}$, Flavio Renan Paula da Costa Alcântara, $\mathrm{MD}_{11}$, Ângelo Macedo Ribeiro, $\mathrm{MD}_{11}$, Felipe Oliveira de Almeida, $\mathrm{MD}_{11}$, Adailson Antonio de Souza Silva, $\mathrm{MD}_{11}$, Suzyane Serfaty do Rosario, $\mathrm{MD}_{12}$, Raysa Wanzeller de Souza Paulain, $\mathrm{MD}_{7}$, Alessandra Reis DDS, PhD 13 , Marissa Li, $\mathrm{MD}_{2}$, Claudia Elizabeth Thompson, $\mathrm{PhD}_{14}$, Gerard J. Nau, MD, $\mathrm{PhD}_{15}$, Carlos Gustavo Wambier, $\mathrm{MD}, \mathrm{PhD}_{5}$, Andy Goren, $\mathrm{MD}_{2,3}$

${ }_{1}$ Corpometria Institute, Brasilia, Brazil.

${ }_{2}$ Applied Biology, Inc. Irvine, CA, USA.

${ }_{3}$ Samel \& Oscar Nicolau Hospitals, Manaus, Brazil

${ }_{4}$ Hospital da Brigada Militar, Porto Alegre, Brazil

${ }_{5}$ Department of Dermatology, Alpert Medical School of Brown University, Providence, RI, USA.

${ }_{6}$ Hospital Regional José Mendes, Itacoatiara, Amazonas, Brazil

${ }_{7}$ Hospital Municipal Jofre Cohen, Parintins, Amazonas, Brazil

${ }_{8}$ Centro de Doenças Renais do Amazonas, Manaus, Brazil

9Programa de Pós-Graduação em Medicina Tropical - FMT/UEA, Manaus, Brazil

${ }_{10}$ Hospital Raimunda Francisca Dinelli da Silva, Maues, Amazonas, Brazil

${ }_{11}$ Hospital de Campanha de Manacapuru, Manacapuru, Amazonas, Brazil

${ }_{12}$ Hospital Regional Dr. Hamilton Maia Cidae, Manicore, Amazonas, Brazil

${ }_{13}$ Department of Restorative Dentistry, State University of Ponta Grossa, Ponta Grossa, Parana, Brazil.

${ }_{14}$ Department of Pharmacosciences, Universidade Federal de Ciências da Saúde de Porto Alegre

${ }_{15}$ Division of Infectious Diseases, Department of Medicine, Alpert Medical School of Brown University, Providence, RI, USA.

\author{
*Corresponding author: \\ John McCoy, PhD \\ Applied Biology, Inc. \\ 17780 Fitch \\ Irvine, CA 92614 \\ johnm@appliedbiology.com
}


medRxiv preprint doi: https://doi.org/10.1101/2021.06.22.21259318; this version posted June 22, 2021. The copyright holder for this preprint (which was not certified by peer review) is the author/funder, who has granted medRxiv a license to display the preprint in perpetuity.

Funding sources: This investigator-initiated trial was supported by an unconditional research grant from Kintor Pharmaceuticals, Ltd. to Applied Biology, Inc., which provided study drugs at no cost. Kintor Pharmaceuticals, Ltd. had no role in the design of the study, data collection, analysis, interpretation of data, or in writing the manuscript, and provided no financial support to the hospitals, or to investigators.

Conflicts of Interest: Kintor Pharmaceuticals, Ltd. manufactures and plans to market proxalutamide for COVID-19. Applied Biology, Inc. has patents pending regarding antiandrogen therapy for COVID-19. Dr. Goren, Dr. McCoy, and Dr. Li are employees of Applied Biology, Inc. Dr. Cadegiani has served as a clinical director for Applied Biology, Inc. Dr. Wambier has served as an advisor to Applied Biology, Inc. The other authors have no conflict of interest to declare.

Authorship statement: Dr. Cadegiani was the principal investigator and contributed to the trial design but was not involved in the direct care of the patients. Dr Goren was the study director and assisted with the trial design and was not involved in direct care of the patients. Dr. Cadegiani, Dr. McCoy, Dr. Mirza, Dr. Nau, Dr. Zimerman, Dr. Reis, Dr. Wambier, and Dr. Goren wrote the manuscript, which was approved by all authors. Dr. Fonseca, Dr. Correia, Dr. Gomes, Dr. Onety, Dr. Israel, Dr. Ferreira, Dr. Alcântara, Dr. Ribeiro, Dr. Oliveira de Almeida, Dr. de Souza Silva, Dr. Rosario, Dr. de Almeida were local investigators involved with direct care of patients, data collection, and reporting. Medical and nursing students: Almeida, Guerreiro, Medeiros, Nicolau, Mendonça Nicolau, Cunha, Barroco, da Silva assisted the local investigators. Dr. Cadegiani and Dr. Goren conducted data and safety monitoring and were unblinded for interim analyses. Dr. Wambier, Dr. Mirza, and Dr. Reis performed the statistical analysis and figures. Dr. Goren and Dr. Wambier contributed equally as senior authors.

IRB approval status: The study was approved by an ethics committee and registered in clinicaltrials.gov (NCT04728802), and also approved by Brazilian National Ethics Committee, approval number 4.513.425; CAAE 41909121.0.0000.5553.

Abstract word count: 259; Manuscript word count: 3280 .

References: 31, Tables: 3, Figures: 3

Keywords: COVID-19; SARS-CoV-2; androgen receptor; antiandrogens; sepsis; clinical trial; transmembrane protease serine 2; pandemic; TMPRSS2; proxalutamide. 
medRxiv preprint doi: https://doi.org/10.1101/2021.06.22.21259318; this version posted June 22, 2021. The copyright holder for this preprint (which was not certified by peer review) is the author/funder, who has granted medRxiv a license to display the preprint in perpetuity.

It is made available under a CC-BY-NC-ND 4.0 International license .

\begin{abstract}
Background: Severe acute respiratory syndrome coronavirus 2 (SARS-CoV-2) infectivity is mediated by the androgen-promoted protease, transmembrane protease, serine 2 (TMPRSS2). Previously, we have shown that treatment with proxalutamide, a nonsteroidal androgen receptor antagonist, accelerates viral clearance and clinical remission in outpatients with coronavirus disease 2019 (COVID-19) compared to placebo. The effects in hospitalized COVID-19 patients were unknown.
\end{abstract}

Methods: Men and women hospitalized but not requiring mechanical ventilation were randomized (1:1 ratio) to receive $300 \mathrm{mg}$ of proxalutamide per day or placebo for 14 days. The study was conducted at eight sites in the state of Amazonas, Brazil. The primary outcome measure was the clinical status (8-point ordinal scale) at 14-days postrandomization. The primary efficacy endpoint was the 14-day recovery ratio (alive hospital discharge [scores 1,2]).

Findings: A total of 645 patients were randomized (317 received proxalutamide, 328 placebo) and underwent intention-to-treat analysis. The 14-day median ordinal scale score in the proxalutamide group was 1 (interquartile range $[\mathrm{IQR}]=1-2)$ versus $7(\mathrm{IQR}=2-8)$ for placebo, $\mathrm{P}<0.001$. The 14 -day recovery rate was $81.4 \%$ for proxalutamide and $35.7 \%$ for placebo (recovery ratio, 2.28; 95\% CI 1.95-2.66 [P<0.001]). The 28-day all-cause mortality rate was $11.0 \%$ for proxalutamide versus $49.4 \%$ for placebo (hazard ratio, 0.16 ; 95\% CI $0.11-0.24)$. The median post-randomization time to recovery was 5 days (IQR=38) for proxalutamide versus 10 days ( $\mathrm{IQR}=6-15)$ for placebo.

Interpretation: Hospitalized COVID-19 patients not requiring mechanical ventilation receiving proxalutamide had a $128 \%$ higher recovery rate than those treated with placebo. All-cause mortality was reduced by $77.7 \%$ over 28 days. (ClinicalTrials.gov number, NCT04728802). 
medRxiv preprint doi: https://doi.org/10.1101/2021.06.22.21259318; this version posted June 22, 2021. The copyright holder for this preprint (which was not certified by peer review) is the author/funder, who has granted medRxiv a license to display the preprint in perpetuity.

It is made available under a CC-BY-NC-ND 4.0 International license .

\section{Introduction}

Severe acute respiratory syndrome coronavirus 2 (SARS-CoV-2) and the resulting coronavirus disease 2019 (COVID-19) has claimed 2.6 million lives globally since it first emerged in December of 2019. ${ }^{1}$ SARS-CoV-2 infects type II pneumocytes in the human lung and endothelial cells by anchoring to angiotensin-converting enzyme 2 (ACE2) receptors. Prior to binding to ACE2, spike proteins on the viral surface undergo structural modification via endogenous transmembrane protease, serine 2 (TMPRSS2). ${ }^{2}$ Because of this modification, Hoffman, et al. proposed that inhibitors of TMPRSS2 would limit SARSCoV-2 infection. ${ }^{2}$ The TMPRSS2 promoter includes a 15 base pair androgen response element. $^{3}$ This led our group to hypothesize that antiandrogen drugs would be good candidates for limiting SARS-CoV-2 entry into cells. ${ }^{4}$ While the mechanism of action of antiandrogens against SARS-CoV-2 is not fully elucidated, pre-clinical studies have shown that nonsteroidal antiandrogens down regulate TMPRSS2 $2^{5}$ and inhibit viral replication in human cell culture..$^{6,7}$

Proxalutamide is a second-generation nonsteroidal androgen receptor antagonist that is more potent than other antiandrogen compounds such as enzalutamide or bicalutamide. ${ }^{8}$ These compounds competitively inhibit androgen binding, block androgen receptor nuclear translocation, and prevent their binding to DNA. ${ }^{9}$ We previously studied the use of proxalutamide, in SARS-CoV-2 positive men in an outpatient setting. In a double-blinded, placebo-controlled, randomized clinical trial, men treated with proxalutamide (200 mg/day) demonstrated significantly reduced hospitalization rates, accelerated improvements of COVID-19 symptoms, and accelerated viral clearance. ${ }^{10}$ Proxalutamide also reduced the duration of COVID-19 in both men and women diagnosed 
medRxiv preprint doi: https://doi.org/10.1101/2021.06.22.21259318; this version posted June 22, 2021. The copyright holder for this preprint (which was not certified by peer review) is the author/funder, who has granted medRxiv a license to display the preprint in perpetuity.

It is made available under a CC-BY-NC-ND 4.0 International license.

with COVID-19 in the outpatient setting. ${ }^{11}$ Here, we evaluated the efficacy of proxalutamide compared to the usual care in hospitalized men and women with COVID-

19. 
medRxiv preprint doi: https://doi.org/10.1101/2021.06.22.21259318; this version posted June 22, 2021. The copyright holder for this preprint (which was not certified by peer review) is the author/funder, who has granted medRxiv a license to display the preprint in perpetuity.

It is made available under a CC-BY-NC-ND 4.0 International license .

\section{Methods}

Trial Design, Setting and Locations

This was a double-blinded, randomized, placebo-controlled, prospective, two-arm trial. The trial was conducted at eight centers in six cities of the state of Amazonas, Brazil from February 1 to April 15, 2021, including enrollment and follow-up.

\section{Eligibility criteria}

Inclusion criteria: Men and women hospitalized due to COVID-19 with a previously confirmed positive test for SARS-CoV-2 within 7 days prior to randomization. SARS-CoV-2 status was determined by real-time reverse transcription polymerase chain reaction (rtPCR) testing following the Cobas SARS-CoV-2 rtPCR kit test protocol (Roche, USA).

Exclusion criteria included mechanical ventilation at the time of randomization, a history of congestive heart failure class III or IV (New York Heart Association), immunosuppression, alanine transferase (ALT) above five times ULN ( $>250 \mathrm{U} / \mathrm{L})$, creatinine above $2.5 \mathrm{mg} / \mathrm{ml}$, or a calculated eGFR was below $30 \mathrm{ml} / \mathrm{min}$. Patients currently using any antiandrogen medications were also excluded. In female patients, those that were pregnant, breastfeeding, or were planning to become pregnant within 90 days were also excluded.

Patients were randomized to receive either proxalutamide $300 \mathrm{mg} /$ day plus usual care or a placebo plus usual care for 14 days in a 1:1 ratio. If patients were discharged before 14 days, they were instructed to continue treatment. Therapy compliance was monitored daily.

Procedures 
medRxiv preprint doi: https://doi.org/10.1101/2021.06.22.21259318; this version posted June 22, 2021. The copyright holder for this preprint

The COVID-19 8-point ordinal scale was used for screening (day 0) as well as daily clinical assessments of patients on days 1-14 (or inpatient after day 14), as well as day 21, and day 28 (if outpatient), resulting in a maximum of 17 data points for each patient. The clinical score is defined as: 8 . Death; 7. Hospitalized, on invasive mechanical ventilation; 6. Hospitalized, on non-invasive ventilation or high flow oxygen devices; 5. Hospitalized, requiring supplemental oxygen; 4. Hospitalized, not requiring supplemental oxygenrequiring ongoing medical care (COVID-19 related or otherwise); 3. Hospitalized, not requiring supplemental oxygen - no longer requires ongoing medical care; 2. Not hospitalized, limitation on activities; and 1. Not hospitalized, no limitations on activities. ${ }^{12}$

Participants discharged from the hospital were evaluated by investigators in followup appointments whenever possible, or by daily phone calls. Upon hospital discharge, patients were instructed to contact the same hospital and the local study team in case of relapse or new symptoms. Hospital readmissions were actively surveilled in all sites.

Baseline characteristics, previous medical history, and concomitant medications were recorded for each patient. Proxalutamide $300 \mathrm{mg} /$ day or placebo plus usual care was given for 14 days, even when COVID-19 remission occurred before this period. Usual care included medications such as enoxaparin, colchicine, methylprednisolone, dexamethasone, or antibiotic therapy if necessary.

Before the onset of the trial, a random sequence was created using a web-based randomization software ${ }^{13}$ using 4, 6 and 8 block sizes and a list length for 662 treatments. The randomization sequence and the allocation concealment were performed remotely from the patient recruiting centers and it was not stratified by site. Pre-packing of tablets of either active or placebo group was manufactured to appear identical (Kintor 
medRxiv preprint doi: https://doi.org/10.1101/2021.06.22.21259318; this version posted June 22, 2021. The copyright holder for this preprint (which was not certified by peer review) is the author/funder, who has granted medRxiv a license to display the preprint in perpetuity.

It is made available under a CC-BY-NC-ND 4.0 International license .

Pharmaceuticals Ltd. Suzhou, China). The procedure is detailed in the Supplementary

\section{Appendix.}

The local investigators who were directly involved with patient care, other healthcare providers, and patients were kept blinded to the group assignments until all patients completed the 28-day post-randomization period and the data was locked. The principal investigator was unblinded for data and safety analysis in March 2021. The interim analysis was conducted on March $10^{\text {th }} 2021$, when the primary outcome measure was reported for a total of 590 patients.

\section{Outcomes and Statistical Analysis}

The primary outcome measure was the 8-point COVD-19 ordinal scale at postrandomization day 14 . The primary efficacy endpoint measure was the overall recovery ratio, which was calculated from recovery rates in each group. Recovery was defined as achieving alive hospital discharge (scores 1 and 2). The secondary outcome measures included recovery rate and all-cause mortality rate (score 8 ) and respective risk ratios at post-randomization day 28; all-cause mortality hazard ratio; median hospitalization time; and median post-randomization time to recover (alive hospital discharge). Subgroup analysis included sex and baseline scores.

An intention-to-treat protocol was used for data analysis. The Wilcoxon Rank Sum test was used to assess the differences of the ordinal scale scores at 14 and 28 days. Risk ratios were calculated to measure the effects of proxalutamide versus placebo on the recovery and all-cause mortality rates. Additional analysis included the recovery and mortality risk ratios by gender, baseline COVID-19 ordinal score, and hospital site. To 
evaluate the all-cause mortality and recovery over the 28-days post-randomization observation period, we used Kaplan-Meier's survivor function for estimates of proportion surviving and failure function for estimates of alive hospital discharges. Cox proportional hazards model was used to calculate hazard ratio (HR) for all-cause mortality over 28 days and its 95\% confidence interval (CI). Graphical assessment and Kaplan-Meier versus predicted survival showed that of the proportional-hazards assumption has not been violated, Figure S3.

The sample size was calculated to be able to detect a difference of approximately $14 \%$ in the overall recovery rate at 14 days (risk ratio of 1.36 ) with a power of $90 \%$ and a type I error of 5\%, over an estimated 39\% recovery rate for the placebo group (based on the protocol for NCT04280705 [scenario 4]), and 3.5\% non-compliance/cross over for each group. Statistical significance was set at $\mathrm{P}<0.05$ and no correction for multiple comparisons was performed. Stata/SE version 16.1 for Mac (StataCorp LLC, College Station, TX, USA) was used to perform all statistical analysis. 
medRxiv preprint doi: https://doi.org/10.1101/2021.06.22.21259318; this version posted June 22, 2021. The copyright holder for this preprint (which was not certified by peer review) is the author/funder, who has granted medRxiv a license to display the preprint in perpetuity.

It is made available under a CC-BY-NC-ND 4.0 International license .

\section{Results}

Patients

Between February 1 and March 17, 2021, 697 patients were assessed for eligibility, including 396 males (56.8\%) and 301 females (43.2\%). At screening, twelve patients did not meet the eligibility criteria as they had kidney failure or liver abnormal enzymes $(1.7 \%)$ and forty patients declined enrollment (5.7\%). Of the 697 patients initially assessed, 645 underwent randomization. Three hundred seventeen patients were randomized to receive proxalutamide in addition to usual care, including 184 males (58.0\%) and 133 females (42.0\%). Three hundred twenty-eight were assigned to receive placebo in addition to usual care, including 182 males (55.5\%) and 146 females (44.5\%). After randomization, 29 of the $317(9.1 \%)$ patients receiving proxalutamide and 36 of the $328(10.9 \%)$ receiving placebo did not complete the trial protocol, the reasons are described in Figure 1.

The baseline characteristics of the study populations are described in Table 1. The median age was 50 years (interquartile range [IQR], 41 to 62) and 49 years (IQR, 38 to 61) for the proxalutamide and placebo groups, respectively. Patients with a body mass index (BMI) above $30 \mathrm{~kg} / \mathrm{m}^{2}$, hypertension, type 2 diabetes mellitus (T2DM), and chronic obstructive pulmonary disorder (COPD) were equally distributed between study arms. No comorbidities, one comorbidity, and two or more comorbidities were present in $69.4 \%$, $17.3 \%$, and $13.3 \%$ of participants, respectively, and were equally distributed between study arms. Median time from hospitalization to randomization was 2 days (IQR 1 to 4.2) for placebo and 2 days (IQR 1 to 4 ) for proxalutamide.

The ordinal scale scores at baseline were 6,5 , and 4 in $66.5 \%, 30.4 \%$, and $2.8 \%$ of the population, respectively. The distribution of ordinal scale score was similar between 
medRxiv preprint doi: https://doi.org/10.1101/2021.06.22.21259318; this version posted June 22, 2021. The copyright holder for this preprint (which was not certified by peer review) is the author/funder, who has granted medRxiv a license to display the preprint in perpetuity.

It is made available under a CC-BY-NC-ND 4.0 International license .

proxalutamide and placebo arms. Except for colchicine, all concomitant medications were used at similar proportions between the groups. Remdesivir was not a treatment option (emergency use authorization dated March 12, 2021 in Brazil). ${ }^{14}$ Compliance with the 14day treatment was $91 \%$ and $89 \%$ for the proxalutamide and placebo arms, respectively. Of note, since the study was conducted in Brazil, the population is ethnically mixed and the majority of patients did not identify themselves as Caucasian, black, or Asian.

\section{Primary Outcome}

At the 14-day timepoint, a lower score distribution was observed for the proxalutamide group than in the placebo group, Figure 2A. The median score in the proxalutamide group was 1 (IQR 1 to 2 ) versus 7 (IQR 2 to 8 ) for placebo ( $<<0.001$ ), Table 2. The overall 14-day recovery rate for placebo of $35.7 \%(95 \%$ CI 30.7 to 40.1$)$ was lower than for proxalutamide $(81.4 \%$; $95 \%$ CI 76.7 to 85.3$), P<0.001$. The 14 -day recovery ratio was $2.28(95 \%$ CI 1.95 to $2.66[\mathrm{P}<0.001])$, which indicates patients who took proxalutamide had a $128 \%$ higher recovery rate than those treated with placebo $(95 \% \mathrm{CI}$ 95 to $166 \%$ ). No interaction effect of the primary outcome and gender was observed, Table 2 and Figure 2B.

\section{Secondary Outcomes}

At the 28-day timepoint, a lower score distribution was observed for the proxalutamide group than in the placebo group, Figure 2A. The median ordinal scale score was 1 (IQR 1-1) for proxalutamide versus 7 (IQR 2 to 8) for placebo. No difference was observed between sexes upon stratification for both placebo and proxalutamide at 28 days, 
medRxiv preprint doi: https://doi.org/10.1101/2021.06.22.21259318; this version posted June 22, 2021. The copyright holder for this preprint (which was not certified by peer review) is the author/funder, who has granted medRxiv a license to display the preprint in perpetuity.

It is made available under a CC-BY-NC-ND 4.0 International license .

Figure 2B. The overall 28-day recovery ratio was 1.81 (95\% CI 1.60 to 2.00$)$, which indicates that patients who took proxalutamide had an $81 \%$ higher recovery rate than those treated with placebo (95\% CI 60 to 100), Table 2.

A high risk of all-cause mortality was observed for placebo (49.4\%; 95\% CI 44.0 to 54.7$)$ compared to proxalutamide $(11.0 \% ; 95 \%$ CI 8.0 to 14.9$)$. The number needed to treat (NNT) to prevent one death from COVID-19 in hospitalized patients over 28 days was 3 (95\% CI 3 to 2). The risk ratio for death was 0.22 (95\% CI 0.16 to 0.31$)$, which indicates that treatment with proxalutamide reduced all-cause mortality rate over 28 days by $77.7 \%$. Subgroup analysis by gender showed no interaction effects in any of the secondary outcome measures, Table 2 . Other subgroup analyses of the 28-day recovery ratio and all-cause mortality risk by city of the study site are present in Tables S3 and S4 of the Supplementary Appendix.

Figure 3 depicts the Kaplan-Meier survival curves and alive hospital discharge within 28 days for both the proxalutamide and placebo treated groups overall. The difference in the proportion surviving was evident as early as day 3 and increased over the remaining study period, which includes days after the 14-day therapy period (Figure 3A). This demonstrates there was no noticeable rebound effect if therapy was completed. The difference in the proportion of alive hospital discharge was statistically significant at day 2, and increased until day 11 , reaching $75 \%$, Figure 3B. Patients in the proxalutamide group during the study period were $84 \%$ (95\% CI $89-76 \%$ ) less likely to die than patients in the control group (hazard ratio for death 0.16 [95\% CI, 0.11 to 0.24$]$ ). The median hospitalization time (days) was lower in the proxalutamide arm (8, IQR 6-13) compared to the placebo (12, IQR 8-18). 
medRxiv preprint doi: https://doi.org/10.1101/2021.06.22.21259318; this version posted June 22, 2021. The copyright holder for this preprint (which was not certified by peer review) is the author/funder, who has granted medRxiv a license to display the preprint in perpetuity.

It is made available under a CC-BY-NC-ND 4.0 International license.

\section{Safety Outcomes}

Adverse events observed during the course of the trial are detailed in Table 3. Adverse events grade 4 or 3 were more commonly observed in the placebo arm $(40.9 \%)$ than in the proxalutamide arm $(2.2 \%), P<0.001$. Diarrhea was the only adverse event reported at higher proportions in those receiving proxalutamide $(16.1 \%)$ versus those receiving placebo $(3.3 \%), P=0.005$. Irritability was reported in four patients treated with proxalutamide $(1.3 \%)$ and none in the placebo group. Among males taking proxalutamide, four reported spontaneous erection $(2.2 \%)$ versus none in males taking placebo. 
medRxiv preprint doi: https://doi.org/10.1101/2021.06.22.21259318; this version posted June 22, 2021. The copyright holder for this preprint (which was not certified by peer review) is the author/funder, who has granted medRxiv a license to display the preprint in perpetuity.

It is made available under a CC-BY-NC-ND 4.0 International license .

\section{Discussion}

Here we demonstrate in a randomized, double-blind, placebo-controlled clinical trial that the use of proxalutamide, a second-generation nonsteroidal antiandrogen, reduced mortality, length of stay, and significantly improved clinical outcomes of hospitalized COVID-19 patients. These findings are consistent with our reports of the efficacy of proxalutamide in an outpatient setting, ${ }^{10,15}$ as well as reports using other antiandrogen regimens, including dutasteride and finasteride. ${ }^{16,17}$

Proxalutamide was a benefit to COVID-19 patients who were severely ill. At the time of the trial, the state of Amazonas experienced a surge in COVID-19 cases resulting in overcrowding at hospitals. As such, prioritized admission to hospitals resulted in admission of the most severely affected patients with COVID-19. Additionally, we found the mortality rate to be exceptionally high $(49.4 \%)$ in the placebo group. Though the observed mortality rate may have been influenced by the emergent P.1 strain, the high mortality rate we observed in the placebo group is not unexpected based on past reports. ${ }^{18,19}$ The northern Amazonas region of Brazil have reported high mortality rates, ranging from 24-55\% amongst hospitalized COVID-19 patients as early as April of 2020, while the average rates observed in all of Brazil range from 14-38\%. ${ }^{18,19}$

As of March, 2021, the P.1 lineage is responsible for at least 70\% of the current SARS-CoV-2 genomes sequenced in Brazil, and for at least $90 \%$ of the SARS-CoV-2 genomes in the state of Amazonas. ${ }^{20}$ In a post-hoc analysis, sequencing of viral genomes from patient samples obtained from the study sites and during the trial dates were found to be the P.1 lineage in all but one case (Supplementary Appendix, Table S5). P.1 is considered one of most relevant variants of concern (VOC) worldwide. This variant has 
medRxiv preprint doi: https://doi.org/10.1101/2021.06.22.21259318; this version posted June 22, 2021. The copyright holder for this preprint (which was not certified by peer review) is the author/funder, who has granted medRxiv a license to display the preprint in perpetuity.

It is made available under a CC-BY-NC-ND 4.0 International license .

demonstrated enhanced affinity for ACE-2 binding, potentially resulting in higher viral loads. ${ }^{21}$ In particular, the E484K substitution, previously demonstrated by our group as being positively selected in diverse lineages in Brazil, ${ }^{22}$ can induce immune escape with consequent reinfection and failure of other therapeutic modalities, such as convalescent plasma. ${ }^{23}$ It is encouraging to note, therefore, that proxalutamide was effective in a region with high P.1 prevalence.

Finding new or repurposed drugs active against VOCs and other SARS-CoV-2 harboring mutations is of paramount importance. Multiple agents have been explored in clinical trials as treatments for COVID-19. To date, the most promising of these treatments are remdesivir, ${ }^{24}$ a viral RNA-polymerase inhibitor, remdesivir plus the Janus kinase (JAK) inhibitor, baricitinib, ${ }^{25}$ and dexamethasone, ${ }^{26}$ a glucocorticoid without mineralocorticoid effect. Remdesivir has been reported to reduce the median time to recovery of hospitalized COVID-19 patients to 10 days, down from 15 days observed with placebo. ${ }^{24}$ The mortality rate of patients treated with remdesivir was $11.4 \%$ at 29 days compared to $15.2 \%$ in the placebo group, though not reaching statistical significance (HR $0.73 ; 95 \% \mathrm{CI}, 0.52$ to 1.03). ${ }^{24}$ Similarly, the combination of remdesivir and baricitinib trended to a reduction in 28-day mortality from $7.8 \%$ to $5.1 \%$ (HR $0.65 ; 95 \% \mathrm{CI}, 0.39$ to 1.09 ). ${ }^{25}$ It is difficult to compare results across trials, but we observed the clinical benefits of proxalutamide to be superior to either of these treatments with greater than $77.7 \%$ reduction in 28 -day mortality rate under ITT analysis (HR of 0.16 ; $95 \% \mathrm{CI}, 0.11$ to 0.24 ). Direct comparisons among therapies are warranted to delineate effective regimen(s). Dexamethasone has also been demonstrated to benefit the most severe COVID-19 patients; among those patients requiring mechanical ventilation, dexamethasone was shown to reduce mortality compared 
medRxiv preprint doi: https://doi.org/10.1101/2021.06.22.21259318; this version posted June 22, 2021. The copyright holder for this preprint (which was not certified by peer review) is the author/funder, who has granted medRxiv a license to display the preprint in perpetuity.

It is made available under a CC-BY-NC-ND 4.0 International license .

to placebo $(29.3 \%$ vs. $41.4 \%$; rate ratio, $0.64 ; 95 \% \mathrm{CI}, 0.51$ to 0.81$) .{ }^{26}$ All of the participants in this trial received corticosteroids, but there was still a survival advantage to receiving proxalutamide.

Treatment emergent adverse events associated with proxalutamide were limited to diarrhea. Diarrhea was also reported to be more frequent among the proxalutamide group in an outpatient trial. ${ }^{11}$ In contrast, severe adverse events of renal failure and hepatic damage were associated with placebo, Table 3. We interpret this finding as the natural progression of COVID-19 in the placebo group, which further supports consideration of proxalutamide as a therapy for hospitalized patients. While Phase 1 safety data for proxalutamide supports its use for 28 days in both men and women (Protocol for details), it has been studied primarily in prostate cancer patients, therefore, long term side effects should be assessed in future studies. Alternatively, other approved molecules of the same class may show similar results, such as apalutamide, enzalutamide, darolutamide, bicalutamide, or flutamide.

Important limitations are present in this study. First, the remote locations of many of the study sites created operational difficulties that led to an unbalanced distribution of proxalutamide and placebo amongst sites (details provided in Supplementary Appendix). Minor differences in effects of proxalutamide between sites may have resulted from factors such as local infrastructure and age distribution (Figures S5 and S6). However, the possibility of effect sizes skewing in favor of the proxalutamide group due to its disproportional concentration in the smaller hospitals is unlikely because a similar size effect was observed in subgroup analysis of all hospital sites (Tables S3 and S4). Second, the severity of patients admitted to Amazonas hospitals during the trial did not allow us to 
medRxiv preprint doi: https://doi.org/10.1101/2021.06.22.21259318; this version posted June 22, 2021. The copyright holder for this preprint (which was not certified by peer review) is the author/funder, who has granted medRxiv a license to display the preprint in perpetuity.

It is made available under a CC-BY-NC-ND 4.0 International license .

test proxalutamide in many hospitalized patients who did not require supplemental oxygen (ordinal score 3). However, we have previously shown that proxalutamide reduced hospitalizations and improved symptom recovery and viral clearance in outpatients with mild-moderate disease. ${ }^{10}$ Moreover, the subgroup analysis showed patients with baseline scores of 3-5 benefited from proxalutamide. Third, more patients used colchicine in the placebo arm despite randomization. This most likely reflects additional therapeutic interventions associated with longer hospitalization in the placebo group. Colchicine is unlikely, however, to have contributed to increased mortality directly as there is either no effect, ${ }^{27}$ with 28 -day mortality rate ratio of 1.01 in the RECOVERY platform trial (95\% CI, 0.93 to 1.10$)^{28}$, or limited benefit in COVID-19. ${ }^{29-31}$ Forth, remdesivir was not available to our patients. Despite the lack of a direct acting antiviral, however, patients receiving proxalutamide had a substantial benefit. Lastly, a dropout rate of approximately $9-11 \%$ was observed in both study arms. The explanation for this participant attrition varied and was seen in both arms, nevertheless, proxalutamide retained its efficacy in the ITT analysis.

This trial has generated important questions requiring further study. Despite being an antiandrogen therapy, women treated with proxalutamide responded similarly to proxalutamide-treated men (Fig 2 and Table 2). Additionally, the significant improvement observed in severely-ill patients appeared disproportionate to the proposed mechanism of reducing viral entry (Table 2, Baseline score 6). These findings suggest additional mechanism(s) of action beyond androgen antagonism and TMPRSS2 knockdown that will require additional investigation. Because of the logistical difficulties executing this trial and the high mortality in Brazil during the study period, our findings 
medRxiv preprint doi: https://doi.org/10.1101/2021.06.22.21259318; this version posted June 22, 2021. The copyright holder for this preprint (which was not certified by peer review) is the author/funder, who has granted medRxiv a license to display the preprint in perpetuity.

It is made available under a CC-BY-NC-ND 4.0 International license.

must be evaluated in other populations. It is urgent that additional trials examine nonsteroidal antiandrogens in different settings.

\section{Conclusions}

Hospitalized COVID-19 patients receiving treatment with proxalutamide had a $128 \%$ higher recovery rate than those treated with placebo at day 14 . All-cause mortality was reduced by $77.7 \%$ over 28 days. Further studies of proxalutamide and other antiandrogen therapies in COVID-19 patients in different settings and locations are urgently needed. 
medRxiv preprint doi: https://doi.org/10.1101/2021.06.22.21259318; this version posted June 22, 2021. The copyright holder for this preprint (which was not certified by peer review) is the author/funder, who has granted medRxiv a license to display the preprint in perpetuity.

It is made available under a CC-BY-NC-ND 4.0 International license .

\section{References}

1. WHO Coronavirus (COVID-19) Dashboard | WHO Coronavirus Disease (COVID19) Dashboard.

2. Hoffmann M, Kleine-Weber H, Schroeder S, et al. SARS-CoV-2 Cell Entry Depends on ACE2 and TMPRSS2 and Is Blocked by a Clinically Proven Protease Inhibitor. Cell. 2020;181(2):271-280.e8. doi:10.1016/j.cell.2020.02.052

3. Lin B, Ferguson C, White JT, et al. Prostate-localized and androgen-regulated expression of the membrane-bound serine protease TMPRSS2. Cancer Res. 1999;59(17):4180-4184. http://www.ncbi.nlm.nih.gov/pubmed/10485450.

4. Wambier CG, Goren A, Vaño-Galván S, et al. Androgen sensitivity gateway to COVID-19 disease severity. Drug Dev Res. 2020;81(7):771-776. doi:10.1002/ddr.21688

5. Wu S, Miao L, Zhou Q, et al. Suppression of Androgen Receptor (AR)ACE2/TMPRSS2 Axis by AR Antagonists May Be Therapeutically Beneficial for Male COVID-19 Patients. SSRN Electron J. April 2020. doi:10.2139/ssrn.3580526

6. Qiao Y, Wang XM, Mannan R, et al. Targeting transcriptional regulation of SARSCoV-2 entry factors ACE2 and TMPRSS2. Proc Natl Acad Sci U S A. 2020;118(1). doi:10.1073/pnas.2021450118

7. Li F, Han M, Dai P, et al. Distinct mechanisms for TMPRSS2 expression explain organ-specific inhibition of SARS-CoV-2 infection by enzalutamide. Nat Commun. 2021;12(1):866. doi:10.1038/s41467-021-21171-X

8. $\mathrm{Qu} \mathrm{F}, \mathrm{Gu} \mathrm{Y,} \mathrm{Wang} \mathrm{Q,} \mathrm{et} \mathrm{al.} \mathrm{Metabolomic} \mathrm{profiling} \mathrm{to} \mathrm{evaluate} \mathrm{the} \mathrm{efficacy} \mathrm{of}$ proxalutamide, a novel androgen receptor antagonist, in prostate cancer cells. Invest New Drugs. 2020;38(5):1292-1302. doi:10.1007/s10637-020-00901-w

9. Tran C, Ouk S, Clegg NJ, et al. Development of a second-generation antiandrogen for treatment of advanced prostate cancer. Science. 2009;324(5928):787-790. doi:10.1126/science. 1168175

10. Applied Biology I. NCT04446429 Anti-Androgen Treatment for COVID-19. Clinicaltrials.gov.

https:/clinicaltrials.gov/ct2/show/results/NCT04446429?view=results. Published 2021. Accessed April 6, 2021. 
medRxiv preprint doi: https://doi.org/10.1101/2021.06.22.21259318; this version posted June 22, 2021. The copyright holder for this preprint (which was not certified by peer review) is the author/funder, who has granted medRxiv a license to display the preprint in perpetuity.

It is made available under a CC-BY-NC-ND 4.0 International license .

11. Cadegiani FA, McCoy J, Gustavo Wambier C, et al. Proxalutamide Significantly Accelerates Viral Clearance and Reduces Time to Clinical Remission in Patients with Mild to Moderate COVID-19: Results from a Randomized, Double-Blinded, Placebo-Controlled Trial. Cureus. February 2021. doi:10.7759/cureus.13492

12. Marshall JC, Murthy S, Diaz J, et al. A minimal common outcome measure set for COVID-19 clinical research. Lancet Infect Dis. 2020;20(8):e192-e197. doi:10.1016/S1473-3099(20)30483-7

13. Sealed Envelope Ltd. Create a blocked randomisation list. Simple Randomiser. https://www.sealedenvelope.com/simple-randomiser/v1/lists. Published 2021. Accessed April 16, 2021.

14. Brasil MDS. Anvisa aprova registro da vacina da Fiocruz/AstraZeneca e de medicamento contra o coronavírus - $\mathrm{O}$ imunizante e o antiviral Rendesivir podem ser usados amplamente no país. gov.br. https://www.gov.br/anvisa/ptbr/assuntos/noticias-anvisa/2021/anvisa-aprova-registro-da-vacina-da-fiocruzastrazeneca-e-de-medicamento-contra-o-coronavirus. Published 2021.

15. McCoy J, Goren A, Vaño-Galvan S, et al. Proxalutamide (GT0918) Reduces the Rate of Hospitalization for COVID-19 Male Outpatients: A Randomized DoubleBlinded Placebo-Controlled Trial. Front Med. 2021;in press. doi:10.3389/fmed.2021.668698

16. Cadegiani FA, McCoy J, Gustavo Wambier C, Goren A. Early Antiandrogen Therapy With Dutasteride Reduces Viral Shedding, Inflammatory Responses, and Time-to-Remission in Males With COVID-19: A Randomized, Double-Blind, Placebo-Controlled Interventional Trial (EAT-DUTA AndroCoV Trial Biochemical). Cureus. February 2021. doi:10.7759/cureus.13047

17. Zarehoseinzade E, Allami A, Ahmadi M, Bijani B, Mohammadi N. Finasteride in hospitalized adult males with COVID-19: A risk factor for severity of the disease or an adjunct treatment: A randomized controlled clinical trial TT -. MJIRI. 2021;35(1):232-237. doi:10.34171/mjiri.35.30

18. Ranzani OT, Bastos LSL, Gelli JGM, et al. Characterisation of the first 250000 hospital admissions for COVID-19 in Brazil: a retrospective analysis of nationwide data. Lancet Respir Med. 2021. doi:10.1016/S2213-2600(20)30560-9 
medRxiv preprint doi: https://doi.org/10.1101/2021.06.22.21259318; this version posted June 22, 2021. The copyright holder for this preprint (which was not certified by peer review) is the author/funder, who has granted medRxiv a license to display the preprint in perpetuity.

It is made available under a CC-BY-NC-ND 4.0 International license .

19. Brasil. Ministério da Saúde. Agência Nacional de Vigilância Sanitária. SRAG 2021 - Severe Acute Respiratory Syndrome Database - including data from COVID-19 SRAG April 12, $2021 \quad$ - Open Data. OpenDataSUS. https://opendatasus.saude.gov.br/dataset/bd-srag-2021. Published 2021. Accessed April 19, 2021.

20. Franceschi VB, Ferrareze PAG, Zimerman RA, Cybis GB, Thompson CE. Mutation hotspots, geographical and temporal distribution of SARS-CoV-2 lineages in Brazil, February 2020 to February 2021: insights and limitations from uneven sequencing efforts. medRxiv. January 2021:2021.03.08.21253152. doi:10.1101/2021.03.08.21253152

21. Golubchik T, Lythgoe KA, Hall M, et al. Early analysis of a potential link between viral load and the N501Y mutation in the SARS-COV-2 spike protein. medRxiv. January 2021:2021.01.12.20249080. doi:10.1101/2021.01.12.20249080

22. Ferrareze PAG, Franceschi VB, de Menezes Mayer A, Caldana GD, Zimerman RA, Thompson CE. E484K as an innovative phylogenetic event for viral evolution: Genomic analysis of the E484K spike mutation in SARS-CoV-2 lineages from Brazil. bioRxiv. January 2021:2021.01.27.426895. doi:10.1101/2021.01.27.426895

23. Nelson G, Buzko O, Spilman P, Niazi K, Rabizadeh S, Soon-Shiong P. Molecular dynamic simulation reveals E484K mutation enhances spike RBD-ACE2 affinity and the combination of E484K, K417N and N501Y mutations (501Y.V2 variant) induces conformational change greater than N501Y mutant alone, potentially resulting in an escap. bioRxiv. January 2021:2021.01.13.426558. doi:10.1101/2021.01.13.426558

24. Beigel JH, Tomashek KM, Dodd LE, et al. Remdesivir for the Treatment of Covid19 - Final Report. N Engl J Med. 2020;383(19):1813-1826. doi:10.1056/nejmoa2007764

25. Kalil AC, Patterson TF, Mehta AK, et al. Baricitinib plus Remdesivir for Hospitalized Adults with Covid-19. N Engl J Med. 2021;384(9):795-807. doi:10.1056/NEJMoa2031994

26. Dexamethasone in Hospitalized Patients with Covid-19 - Preliminary Report. $N$ Engl J Med. 2020;384(8). doi:10.1056/nejmoa2021436 
27. Nuffield Department of Population Health. RECOVERY trial closes recruitment to colchicine treatment for patients hospitalised with COVID-19. https://www.recoverytrial.net/news/recovery-trial-closes-recruitment-tocolchicine-treatment-for-patients-hospitalised-with-covid-19. Published 2021. Accessed April 19, 2021.

28. Horby PW, Campbell M, Spata E, et al. Colchicine in patients admitted to hospital with COVID-19 (RECOVERY): a randomised, controlled, open-label, platform trial. medRxiv. January 2021:2021.05.18.21257267. doi:10.1101/2021.05.18.21257267

29. Manenti L, Maggiore U, Fiaccadori E, et al. Reduced mortality in COVID-19 patients treated with colchicine: Results from a retrospective, observational study. PLoS One. 2021;16(3):e0248276. doi:10.1371/journal.pone.0248276

30. Hariyanto TI, Halim DA, Jodhinata C, Yanto TA, Kurniawan A. Colchicine treatment can improve outcomes of coronavirus disease 2019 (COVID-19): A systematic review and meta-analysis. Clin Exp Pharmacol Physiol. March 2021. doi:10.1111/1440-1681.13488

31. Salah HM, Mehta JL. Meta-analysis of the Effect of Colchicine on Mortality and Mechanical Ventilation in COVID-19. Am J Cardiol. 2021;145:170-172. doi:10.1016/j.amjcard.2021.02.005 
medRxiv preprint doi: https://doi.org/10.1101/2021.06.22.21259318; this version posted June 22, 2021. The copyright holder for this preprint (which was not certified by peer review) is the author/funder, who has granted medRxiv a license to display the preprint in perpetuity.

It is made available under a CC-BY-NC-ND 4.0 International license .

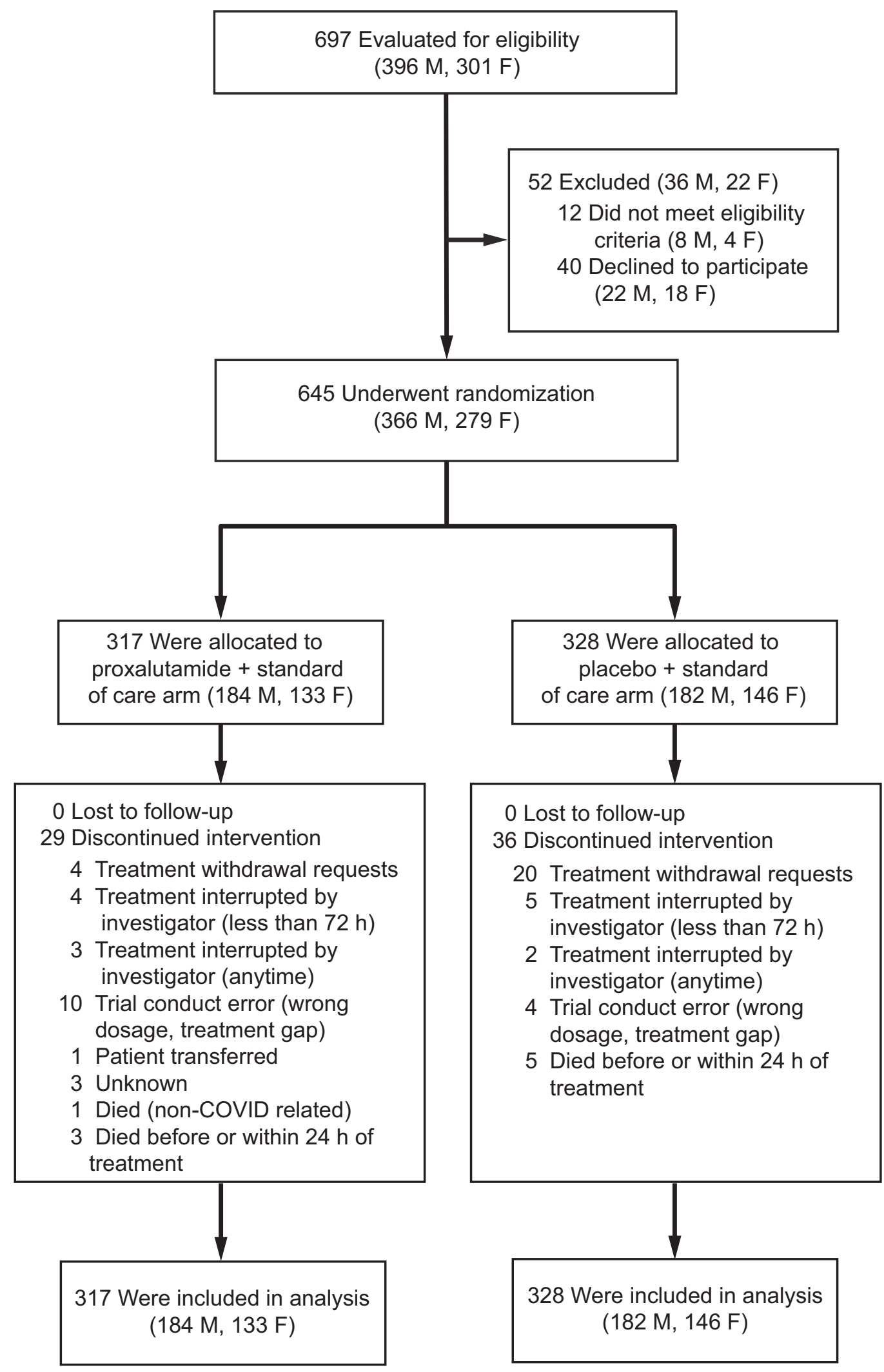

Figure 1. Enrollment and randomization of the studied population. 
medRxiv preprint doi: https://doi.org/10.1101/2021.06.22.21259318; this version posted June 22, 2021. The copyright holder for this preprint (which was not certified by peer review) is the author/funder, who has granted medRxiv a license to display the preprint in perpetuity.

\section{It is made available under a CC-BY-NC-ND 4.0 International license.}

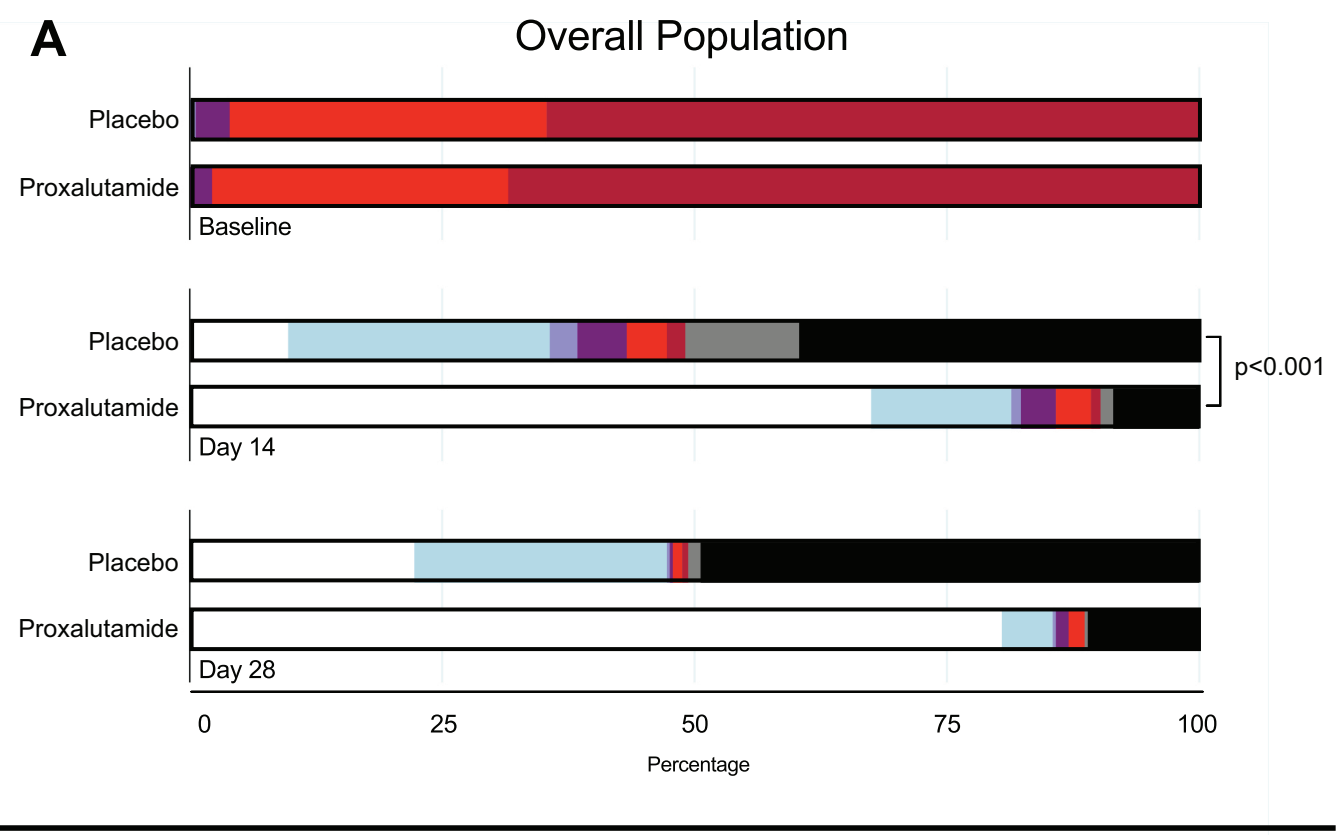

\section{B}
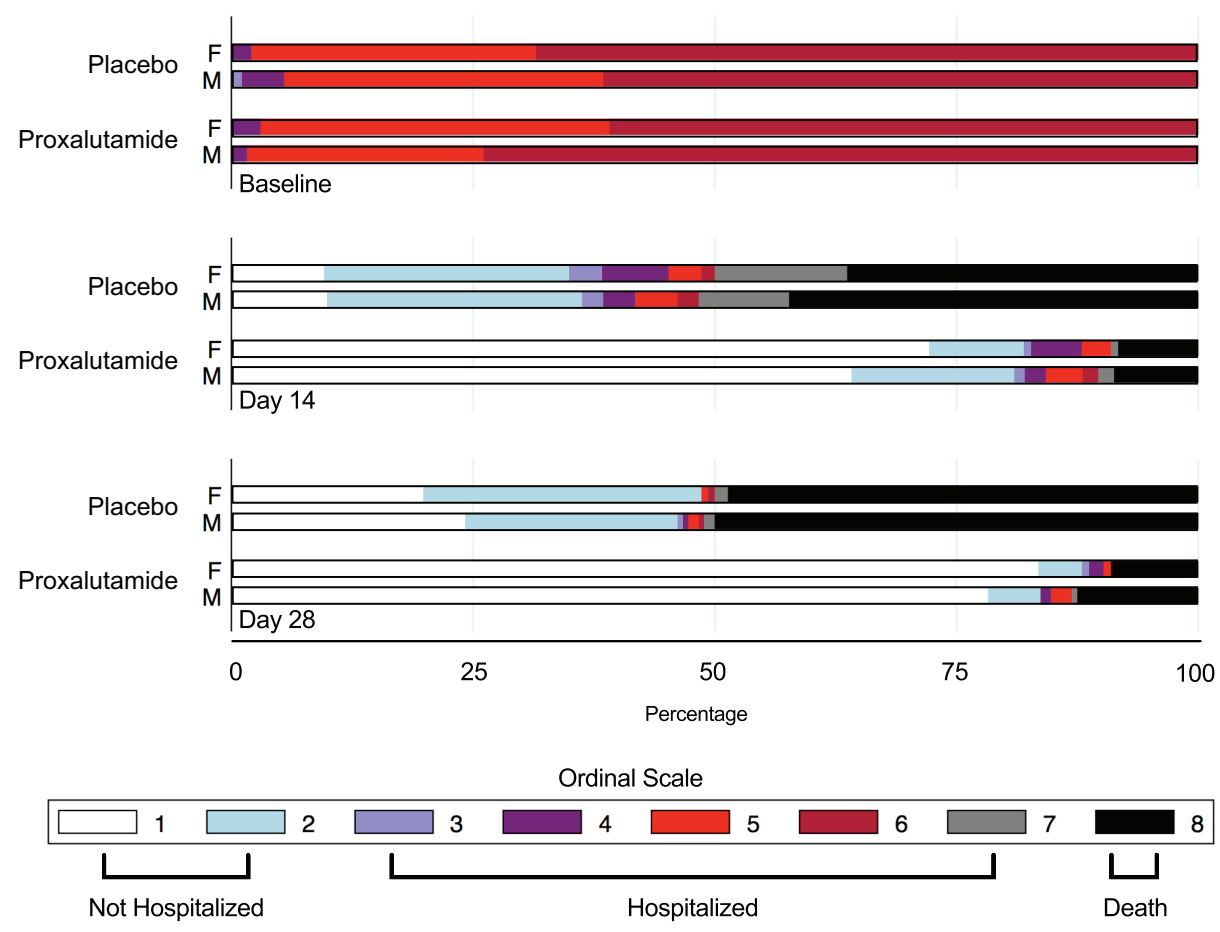

Figure 2. Distribution of the COVID-19 8-Point Ordinal Scale in the Intention-to-Treat

population at randomization, day 14 , and day 28. Data are presented in the overall population (A) and stratified by gender (B). 
medRxiv preprint doi: https://doi.org/10.1101/2021.06.22.21259318; this version posted June 22, 2021. The copyright holder for this preprint (which was not certified by peer review) is the author/funder, who has granted medRxiv a license to display the preprint in perpetuity.

It is made available under a CC-BY-NC-ND 4.0 International license .
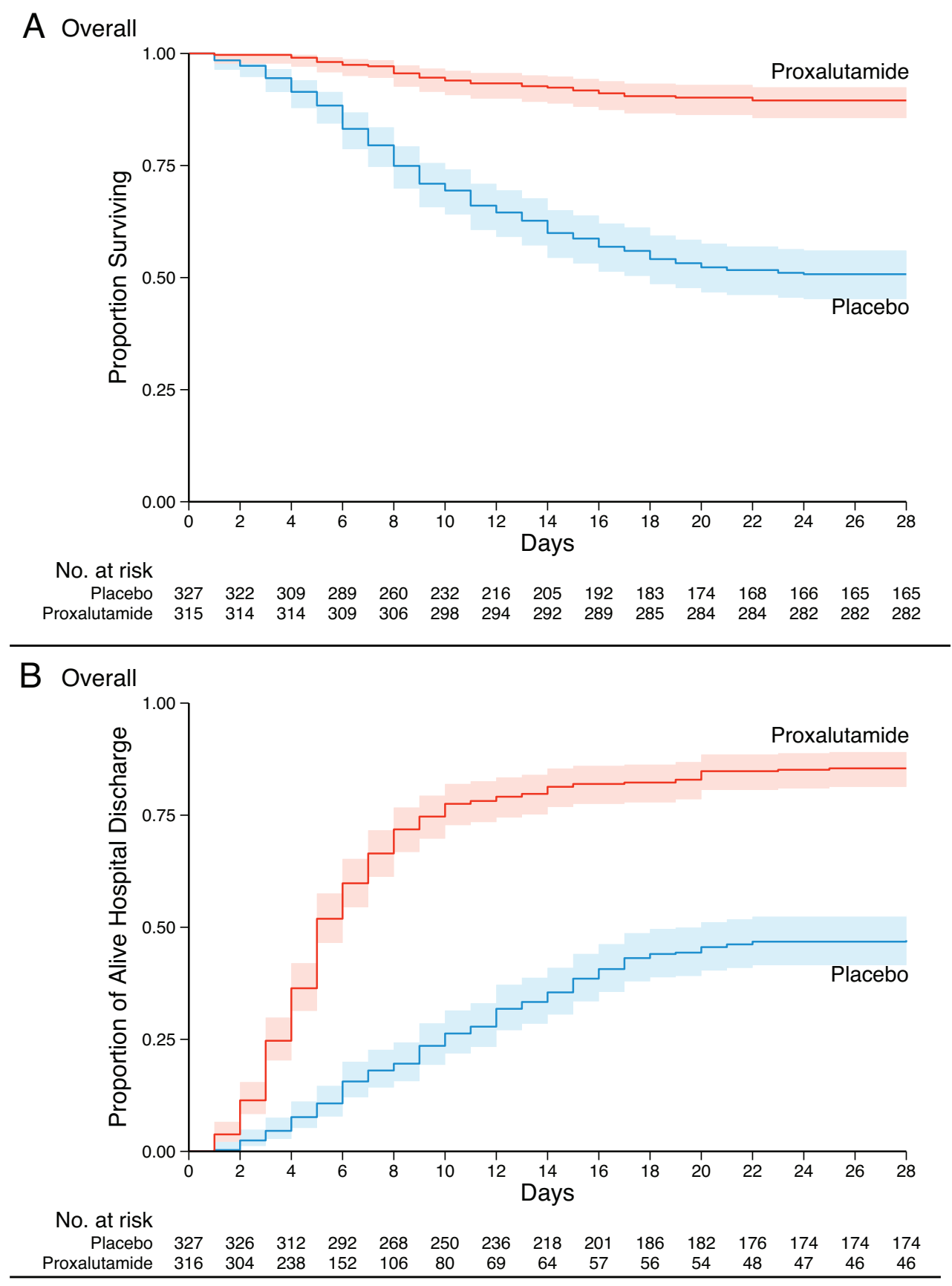

Figure 3. Kaplan-Meier estimates in the intention-to-treat analysis from randomization to day 28. Surviving (Panel A) and Alive Hospital Discharge (Panel B) for the overall population. 
medRxiv preprint doi: https://doi.org/10.1101/2021.06.22.21259318; this version posted June 22, 2021. The copyright holder for this preprint (which was not certified by peer review) is the author/funder, who has granted medRxiv a license to display the preprint in perpetuity.

It is made available under a CC-BY-NC-ND 4.0 International license .

Table 1. Baseline clinical characteristics, comorbidities, and concomitant medications of the studied population $(\mathrm{IQR}=$ interquartile range).

\begin{tabular}{|c|c|c|c|}
\hline Characteristic & $\begin{array}{l}\text { Overall } \\
\mathrm{N}=645\end{array}$ & $\begin{array}{c}\text { Proxalutamide } \\
\mathrm{N}=\mathbf{3 1 7}\end{array}$ & $\begin{array}{c}\text { Placebo } \\
\mathrm{N}=328\end{array}$ \\
\hline \multicolumn{4}{|l|}{ Age } \\
\hline Median - years (IQR) & $50(39-61.5)$ & $50(41-62)$ & $49(38-61)$ \\
\hline$>55$ yr - no. (\%) & $238(36.9)$ & $115(36.3)$ & $123(37.5)$ \\
\hline \multicolumn{4}{|l|}{ Sex-no. (\%) } \\
\hline Female & $279(43.3)$ & $133(42.0)$ & $146(44.5)$ \\
\hline Male & $366(56.7)$ & $184(58.0)$ & $182(55.5)$ \\
\hline Body mass index over $30 \mathrm{~kg} / \mathrm{m}^{2}-$ no. (\%) & $53(8.2)$ & $28(8.8)$ & $25(7.6)$ \\
\hline Hypertension - no. (\%) & $175(27.1)$ & $93(29.3)$ & $82(25.0)$ \\
\hline Type 2 diabetes mellitus - no. (\%) & $79(12.2)$ & $41(12.9)$ & $38(11.6)$ \\
\hline $\begin{array}{l}\text { Chronic obstructive pulmonary disorder } \\
- \text { no. (\%) }\end{array}$ & $16(2.5)$ & $8(2.5)$ & $8(2.4)$ \\
\hline Chronic kidney disease - no. (\%) & $0(0.0)$ & $0(0.0)$ & $0(0.0)$ \\
\hline \multicolumn{4}{|l|}{ Coexisting conditions - no. (\%) } \\
\hline 0 & $431(66.8)$ & $204(64.4)$ & $227(69.2)$ \\
\hline 1 & $124(19.2)$ & $68(21.4)$ & $56(17.1)$ \\
\hline $2+$ & $90(14.0)$ & $45(14.2)$ & $45(13.7)$ \\
\hline $\begin{array}{l}\text { Median time from hospitalization to } \\
\text { randomization (IQR) - days }\end{array}$ & $2.0(1.0-4.0)$ & $2.0(1.0-4.0)$ & $2.0(1.0-4.2)$ \\
\hline \multicolumn{4}{|l|}{$\begin{array}{l}\text { Score on the Coronavirus Disease } 2019 \\
\text { ordinal scale- no. (\%) }\end{array}$} \\
\hline $\begin{array}{l}\text { 3. Hospitalized, not requiring } \\
\text { supplemental oxygen - no longer } \\
\text { requires ongoing medical care }\end{array}$ & $2(0.3)$ & $0(0.0)$ & $2(0.6)$ \\
\hline $\begin{array}{l}\text { 4. Hospitalized, not requiring } \\
\text { supplemental oxygen, requiring } \\
\text { ongoing medical care (COVID-19 } \\
\text { related or otherwise) }\end{array}$ & $18(2.8)$ & $7(2.2)$ & $11(3.3)$ \\
\hline $\begin{array}{l}\text { 5. Hospitalized, requiring } \\
\text { supplemental oxygen }\end{array}$ & $196(30.4)$ & $93(29.3)$ & $103(31.4)$ \\
\hline $\begin{array}{l}\text { 6. Hospitalized, receiving non- } \\
\text { invasive ventilation or high flow } \\
\text { oxygen devices }\end{array}$ & $429(66.5)$ & $217(68.5)$ & $212(64.6)$ \\
\hline \multicolumn{4}{|l|}{ Concomitant medications - no. (\%) } \\
\hline Ceftriaxone & $638(98.9)$ & $313(98.7)$ & $325(99.1)$ \\
\hline Colchicine & $407(63.1)$ & $201(63.4)$ & $306(93.3)$ \\
\hline $\begin{array}{l}\text { Macrolides (azithromycin, } \\
\text { clarithromycin) }\end{array}$ & $631(97.8)$ & $307(96.8)$ & $324(98.8)$ \\
\hline $\begin{array}{l}\text { Glucocorticosteroids } \\
\text { (dexamethasone, } \\
\text { methylprednisolone) } \\
\end{array}$ & $645(100)$ & $317(100)$ & $328(100)$ \\
\hline Enoxaparin & $645(100)$ & $317(100)$ & $328(100)$ \\
\hline Omeprazole & $645(100)$ & $317(100)$ & $328(100)$ \\
\hline
\end{tabular}


medRxiv preprint doi: https://doi.org/10.1101/2021.06.22.21259318; this version posted June 22, 2021. The copyright holder for this preprint (which was not certified by peer review) is the author/funder, who has granted medRxiv a license to display the preprint in perpetuity.

It is made available under a CC-BY-NC-ND 4.0 International license .

Table 2. Outcomes according to treatment group in the intention-to-treat analysis. Recovery rates (reaching scores 1 or 2) over 14 and 28 days after randomization. Allcause mortality rate over 28 days. (IQR $=$ interquartile range, $\mathrm{CI}=$ confidence interval, HR = Hazard Ratio). Subgroup analysis per sex and per baseline score are presented with 95\% CI which have not been adjusted for multiplicity.

\begin{tabular}{|c|c|c|c|c|}
\hline Characteristic & $\begin{array}{l}\text { Overall } \\
\mathrm{N}=645\end{array}$ & $\begin{array}{l}\text { Proxalutamide } \\
\mathrm{N}=317\end{array}$ & $\begin{array}{l}\text { Placebo } \\
\mathrm{N}=328\end{array}$ & Risk ratio (95\% Cl) \\
\hline Day 14 Scores - median (IQR) & $2(1-7)$ & $1(1-2)$ & $7(2-8)$ & $P<0.001$ \\
\hline $\begin{array}{l}\text { Recovery rate over } 14 \text { days, } \\
\text { no. (\%) }\end{array}$ & $375(58.1)$ & $258(81.4)$ & $117(35.7)$ & $2.28(1.95-2.66) \mathrm{P}<0.001$ \\
\hline Females & $160(57.3)$ & $109(82.0)$ & $51(34.9)$ & $2.35(1.85-2.97)$ \\
\hline Males & $215(58.7)$ & $149(81.0)$ & $66(36.3)$ & $2.23(1.82-2.74)$ \\
\hline Baseline Score 3 & $2(100.0)$ & - & $2(100.0)$ & - \\
\hline Baseline Score 4 & $16(88.9)$ & $7(100.0)$ & $9(81.8)$ & $1.22(0.93-1.61)$ \\
\hline Baseline Score 5 & 133 (67.9) & $82(88.2)$ & $51(49.5)$ & $1.78(1.45-2.19)$ \\
\hline Baseline Score 6 & $224(52.2)$ & 169 (77.9) & $55(25.9)$ & $3.00(2.37-3.81)$ \\
\hline $\begin{array}{l}\text { Recovery rate over } 28 \text { days } \\
\text { no. (\%) }\end{array}$ & $426(66.0)$ & $271(85.5)$ & $155(47.3)$ & $1.81(1.60-2.05)$ \\
\hline Females & $188(67.4)$ & $117(88.0)$ & $71(48.6)$ & $1.81(1.51-2.16)$ \\
\hline Males & $238(65.0)$ & $154(83.7)$ & $84(46.2)$ & $1.81(1.53-2.15)$ \\
\hline Baseline Score 4 & $16(88.9)$ & $7(100.0)$ & $9(81.8)$ & $1.22(0.93-1.61)$ \\
\hline Baseline Score 5 & $152(77.6)$ & $86(92.5)$ & $66(64.1)$ & $1.44(1.23-1.69)$ \\
\hline Baseline Score 6 & $256(59.7)$ & $178(82.0)$ & $78(36.8)$ & $2.23(1.85-2.69)$ \\
\hline $\begin{array}{l}\text { All-cause mortality rate over } \\
28 \text { days, no. (\%) }\end{array}$ & $197(30.5)$ & $35(11.0)$ & $162(49.4)$ & $\begin{array}{c}0.22(0.16-0.31) \\
H R 0.16(0.11-0.24])\end{array}$ \\
\hline Females & $83(29.7)$ & $12(9.0)$ & $71(48.6)$ & $0.18(0.11-0.33)$ \\
\hline Males & $114(31.1)$ & $23(12.5)$ & $91(50.0)$ & $0.25(0.17-0.38)$ \\
\hline Baseline Score 4 & $2(11.1)$ & $0(0.0)$ & $2(18.2)$ & 0 \\
\hline Baseline Score 5 & $42(21.4)$ & $5(5.4)$ & 37 (35.9) & $0.15(0.06-0.36)$ \\
\hline Baseline Score 6 & $153(35.7)$ & $30(13.8)$ & $123(58.0)$ & $0.24(0.17-0.34)$ \\
\hline $\begin{array}{l}\text { Median hospitalization days } \\
\text { (IQR) }\end{array}$ & $10(6-16)$ & $8(6-13)$ & $12(8-18)$ & \\
\hline $\begin{array}{l}\text { Post-randomization time to } \\
\text { recover / alive hospital } \\
\text { discharge, median days } \\
\text { (IQR) }\end{array}$ & $6(4-11)$ & $5(3-8)$ & $10(6-15)$ & \\
\hline
\end{tabular}


medRxiv preprint doi: https://doi.org/10.1101/2021.06.22.21259318; this version posted June 22, 2021. The copyright holder for this preprint (which was not certified by peer review) is the author/funder, who has granted medRxiv a license to display the preprint in perpetuity.

It is made available under a CC-BY-NC-ND 4.0 International license .

Table 3. Treatment emergent adverse events (TEAE) in the patient population, per intention-to-treat analysis.

\begin{tabular}{|c|c|c|c|c|}
\hline Characteristic & $\begin{array}{l}\text { Overall } \\
\mathrm{N}=645\end{array}$ & $\begin{array}{l}\text { Proxalutamide } \\
\mathrm{N}=317\end{array}$ & $\begin{array}{c}\text { Placebo } \\
\mathrm{N}=328\end{array}$ & $P$ \\
\hline Number of subjects with 1 or more TEAE & $334(51.8)$ & $109(34.4)$ & $225(68.6)$ & $<0.001$ \\
\hline \multicolumn{5}{|l|}{ Grade $5-n(\%)$} \\
\hline Death, Day 14 & $157(24.3)$ & $27(8.5)$ & $130(39.6)$ & $<0.001$ \\
\hline Females & $64(22.9)$ & $11(8.3)$ & $53(36.3)$ & $<0.001$ \\
\hline Males & $93(25.4)$ & $16(8.7)$ & $77(42.3)$ & $<0.001$ \\
\hline Death, Day 28 & $197(30.5)$ & $35(11.0)$ & $162(49.4)$ & $<0.001$ \\
\hline Females & $83(29.7)$ & $12(9.0)$ & $71(48.6)$ & $<0.001$ \\
\hline Males & $114(31.2)$ & $23(12.5)$ & $91(50.0)$ & $<0.001$ \\
\hline \multicolumn{5}{|l|}{ Grades 4 or $3-n(\%)$} \\
\hline Shock, requiring vasopressors & $141(21.9)$ & $7(2.2)$ & $134(40.9)$ & $<0.001$ \\
\hline Mechanical ventilation, Day 14 & $41(6.4)$ & $4(1.3)$ & $37(11.3)$ & 0.038 \\
\hline Females & $21(7.5)$ & $1(0.8)$ & $20(13.7)$ & 0.089 \\
\hline Males & $20(5.5)$ & $3(1.6)$ & $17(9.3)$ & 0.28 \\
\hline Mechanical ventilation, Day 28 & $46(7.1)$ & $5(1.6)$ & $41(12.5)$ & $<0.001$ \\
\hline Females & $23(8.2)$ & $1(0.8)$ & $22(15.1)$ & $<0.001$ \\
\hline Males & $23(6.3)$ & $4(2.2)$ & $19(10.4)$ & 0.001 \\
\hline Disease progression & $204(31.6)$ & $36(11.4)$ & $168(51.2)$ & $<0.001$ \\
\hline Females & $86(30.8)$ & $12(9.0)$ & $74(50.7)$ & $<0.001$ \\
\hline Males & $118(32.2)$ & $24(13.0)$ & $94(51.6)$ & $<0.001$ \\
\hline Renal failure (creatinine increase $>100 \%$ ) & $26(4.0)$ & $5(1.6)$ & $21(6.4)$ & 0.29 \\
\hline Females & $12(4.3)$ & $1(0.7)$ & $11(7.5)$ & 0.33 \\
\hline Males & $14(3.8)$ & $4(2.2)$ & $10(5.4)$ & 0.58 \\
\hline $\begin{array}{l}\text { Liver damage (ALT > } 250 \mathrm{U} / \mathrm{L} \text { or }>100 \% \\
\text { increase) }\end{array}$ & $23(3.6)$ & $4(1.3)$ & $19(5.8)$ & 0.32 \\
\hline Females & $10(3.6)$ & $0(0.0)$ & $10(6.8)$ & 0.37 \\
\hline Males & $13(3.6)$ & $4(2.2)$ & $9(4.9)$ & 0.65 \\
\hline \multicolumn{5}{|l|}{ Grades 2 or $1-n(\%)$} \\
\hline Diarrhea & $63(9.8)$ & $51(16.1)$ & $11(3.3)$ & 0.005 \\
\hline Females & $29(10.4)$ & $22(16.5)$ & $7(4.8)$ & 0.091 \\
\hline Males & $31(8.5)$ & $29(15.9)$ & $4(1.1)$ & 0.025 \\
\hline Abdominal pain & $4(0.6)$ & $3(0.9)$ & $1(0.3)$ & 0.89 \\
\hline Females & $1(0.4)$ & $1(0.7)$ & $0(0.0)$ & 0.91 \\
\hline Males & $3(0.8)$ & $2(1.1)$ & $1(0.5)$ & 0.93 \\
\hline Irritability & $4(0.6)$ & $4(1.3)$ & $0(0.0)$ & 0.78 \\
\hline Females & $1(0.4)$ & $1(0.7)$ & $0(0.0)$ & 0.91 \\
\hline Males & $3(0.8)$ & $3(1.6)$ & $0(0.0)$ & 0.79 \\
\hline \multicolumn{5}{|l|}{ Spontaneous erection } \\
\hline Males & $4(1.1)$ & $4(2.2)$ & $0(0.0)$ & 0.73 \\
\hline Vomiting, dyspepsia, or palpitations & $0(0.0)$ & $0(0.0)$ & $0(0.0)$ & 1 \\
\hline
\end{tabular}




\section{Efficacy of Proxalutamide in Hospitalized COVID-19 Patients: A Randomized, Double-Blind, Placebo-Controlled, Parallel- Design Clinical Trial}

\section{Table of Contents:}

Additional Clinical Trial Sites Details ...................................................................................... 2

Additional Inclusion and Exclusion Criteria Details ......................................................... 3

Additional Randomization Procedures.................................................................................. 5

Table S1. Group Distribution per Site ....................................................................... 6

Interim Analysis and Public Disclosure, March $10^{\text {th }} 2021$...................................... 7

Figure S1. Randomization/recruitment timeline ............................................................ 7

Dosage Administration and Compliance Procedures ........................................................ 8

Baseline COVID-19 8-point Ordinal Scale ........................................................................ 8

Table S2. Coronavirus disease 2019 8-point ordinal scale scores distribution and

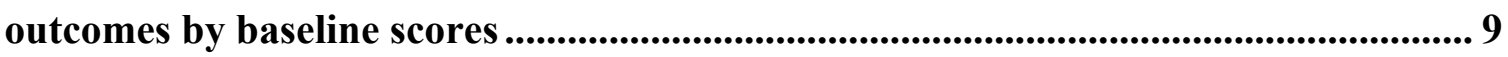

Table S3. Recovery (coronavirus disease 2019 8-point ordinal scale scores 1 or 2, alive hospital discharge) over 14- and 28-days post-randomization stratified by city ...... 10

Table S4. All-cause mortality over 28 days post-randomization stratified by city ... 11

Figure S2. Kaplan-Meier estimates from randomization to Day 28.......................... 12

Figure S3. Graphical assessment of proportional-hazards assumption (hazard ratio over 28 days post-randomization). ................................................................................................ 13

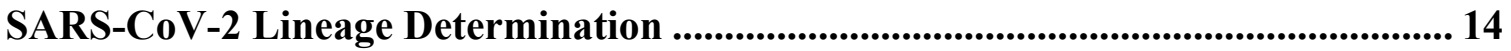

Table S5. Sequencing of SARS-CoV-2 in 44 Randomly Selected Patients ................ 15

Figure S4. Violin Plots for Age, for alive hospital discharge over the first 14 days postrandomization, per treatment group................................................................................... 16

Figure S5. Violin Plots for Age, for all-cause mortality over the 28 days postrandomization, per treatment group............................................................................... 16

Figure S6. Violin Plots for Age, for cities, per treatment group................................. 17 


\section{Supplementary Appendix}

medRxiv preprint doi: https://doi.org/10.1101/2021.06.22.21259318; this version posted June 22, 2021. The copyright holder for this preprint (which was not certified by peer review) is the author/funder, who has granted medRxiv a license to display the preprint in perpetuity. It is made available under a CC-BY-NC-ND 4.0 International license .

\section{Additional Clinical Trial Sites Details}

12 sites were approved to recruit patients. However, recruitment of patients was rapid and 4 sites were not able to participate before the trial had reached recruitment goals.

Sites that recruited patients during the trial and number of patients randomized (n):

1. Hospital Samel, Manaus, Amazonas, Brazil (99)

2. Hospital Oscar Nicolau, Manaus, Amazonas, Brazil (108)

3. Hospital Prontocord, Manaus, Amazonas, Brazil (188)

4. Hospital Regional José Mendes, Itacoatiara, Amazonas, Brazil (112)

5. Hospital Raimunda Francisca Dinelli da Silva, Maues, Amazonas, Brazil (12)

6. Hospital Regional Dr. Hamilton Maia Cidae, Manicore, Amazonas, Brazil (5)

7. Hospital Regional Jofre Cohen, Parintins, Amazonas, Brazil (103)

8. Hospital de Campanha de Manacapuru, Manacapuru, Amazonas, Brazil (18)

\section{Manaus, Amazonas, Brazil: 395 patients randomized \\ Other cities, Amazonas, Brazil: 250 patients randomized}

Sites approved to participate in the study that did not recruit patients before trial closed enrollment (no patients randomized):

9. Hospital Regional de Coari Prof. Dr. Odair Carlos Geraldo, Coari, Amazonas, Brazil

10. Hospital de Campanha de Barcelos, Barcelos, Amazonas, Brazil

11. Hospital Regional de Labrea, Labrea, Amazonas, Brazil

12. Hospital Regional de Humaitá, Humaitá, Amazonas, Brazil 


\section{Supplementary Appendix}

medRxiv preprint doi: https://doi.org/10.1101/2021.06.22.21259318; this version posted June 22, 2021. The copyright holder for this preprint (which was not certified by peer review) is the author/funder, who has granted medRxiv a license to display the preprint in perpetuity. It is made available under a CC-BY-NC-ND 4.0 International license .

Additional Inclusion and Exclusion Criteria Details

\section{Inclusion Criteria}

Subjects enrolled in this study were required to meet the following key acceptance criteria:

- Admitted to the hospital with symptoms of COVID-19

- Male and females age $\geq 18$ years old

- Laboratory confirmed positive SARS-CoV-2 rtPCR test within 7 days prior to randomization

- Clinical status on the COVID-19 Ordinal Scale of 3, 4, 5, or 6

- Coagulation: INR $\leq 1.5 \times \mathrm{ULN}$, and APTT $\leq 1.5 \times \mathrm{ULN}$

- Subject (or legally authorized representative) gives written informed consent prior to performing any study procedures

- Subject (or legally authorized representative) agree that subject will not participate in another COVID-19 trial while participating in this study

\section{Exclusion Criteria}

Subjects were not to be enrolled into the study if it was determined upon pre-study examination that they met the following key criteria:

- Subject enrolled in a study to investigate a treatment for COVID-19

- Requires mechanical ventilation

- Subject taking an anti-androgen of any type including: androgen depravation therapy, 5-alpha reductase inhibitors, etc.

- Patients who are allergic to the investigational product or similar drugs (or any excipients);

- Subjects who have malignant tumors in the past 5 years, with the exception of completed resected basal cell and squamous cell skin cancer and completely resected carcinoma in situ of any type

- Subjects with known serious cardiovascular diseases, congenital long QT syndrome, torsade de pointes, myocardial infarction in the past 6 months, or arterial thrombosis, or unstable angina pectoris, or congestive heart failure which is classified as New York Heart Association (NYHA) class 3 or higher, or left ventricular ejection fraction $(\mathrm{LVEF})<50 \%$, QTcF $>450 \mathrm{~ms}$

- Subjects with uncontrolled medical conditions that could compromise participation in the study (e.g., uncontrolled hypertension, hypothyroidism, diabetes mellitus)

- Known diagnosis of human immunodeficiency virus (HIV), hepatitis C, active hepatitis $\mathrm{B}$, treponema pallidum (testing is not mandatory)

- Alanine Transaminase (ALT) or Aspartate Transaminase (AST) $>5$ times the upper limit of normal.

- Estimated glomerular filtration rate $(\mathrm{eGFR})<30 \mathrm{ml} / \mathrm{min}$

- Severe kidney disease requiring dialysis

- Women of child-bearing potential, defined as all women physiologically capable of becoming pregnant, unless they are using highly effective contraception, as shown below, throughout the study and for 3 months after stopping GT0918 treatment. Highly effective contraception methods include: 


\section{Supplementary Appendix}

medRxiv preprint doi: https://doi.org/10.1101/2021.06.22.21259318; this version posted June 22, 2021. The copyright holder for this preprint (which was not certified by peer review) is the author/funder, who has granted medRxiv a license to display the preprint in perpetuity. It is made available under a CC-BY-NC-ND 4.0 International license.

1. Total Abstinence (when this is in line with the preferred and usual lifestyle of the patient. Periodic abstinence (e.g., calendar, ovulation, symptothermal, post-ovulation methods) and withdrawal are not acceptable methods of contraception, or

2. Use of one of the following combinations $(a+b$ or $a+c$ or $b+c)$ :

a: Use of oral, injected or implanted hormonal methods of contraception or other forms of hormonal contraception that have comparable efficacy (failure rate $<1 \%$ ), for example hormone vaginal ring or transdermal hormone contraception.

b: Placement of an intrauterine device (IUD) or intrauterine system (IUS) ;

c: Barrier methods of contraception: Condom or Occlusive cap (diaphragm or cervical/vault caps) with spermicidal foam/gel/film/cream/vaginal suppository;

3. Female sterilization (have had prior surgical bilateral oophorectomy with or without hysterectomy) or tubal ligation at least six weeks before taking study treatment. In case of oophorectomy alone, only when the reproductive status of the woman has been confirmed by follow-up hormone level assessment;

4. Male sterilization (at least 6 months prior to screening). For female patients on the study, the vasectomized male partner should be the sole partner for that patient;

5. In case of use of oral contraception women should have been stable for a minimum of 3 months before taking study treatment. Women are considered post-menopausal and not of child bearing potential if they have had 12 months of natural (spontaneous) amenorrhea with an appropriate clinical profile (e.g., age appropriate, history of vasomotor symptoms) or have had surgical bilateral oophorectomy (with or without hysterectomy) or tubal ligation at least six weeks ago. In the case of oophorectomy alone, only when the reproductive status of the woman has been confirmed by follow up hormone level assessment, is she considered not of child bearing potential.

- Sexually active males must use a condom during intercourse while taking the drug and for 3 months after stopping treatment and should not father a child in this period. A condom is required to be used also by vasectomized men in order to prevent delivery of the drug via seminal fluid

- Subject likely to transfer to another hospital within the next 28 days

- Subject (or legally authorized representative) not willing or unable to provide informed consent 


\section{Supplementary Appendix}

medRxiv preprint doi: https://doi.org/10.1101/2021.06.22.21259318; this version posted June 22, 2021. The copyright holder for this preprint (which was not certified by peer review) is the author/funder, who has granted medRxiv a license to display the preprint in perpetuity. It is made available under a CC-BY-NC-ND 4.0 International license. Additional Randomization Procedures

Before the onset of the trial, a randomization table was created using a web-based randomization software (sealedenvelope.com/simple-randomiser/v1/lists) using 4, 6 and 8 block sizes and a list length for 662 treatment packages of identical appearance of either active or placebo group. A pharmacist sealed and labeled each package with a 3-character random-generated code. The packages contained a total of 6 blister packs of 7 individually sealed tablets, which accounted for a total of 42 tablets per treatment. The package instructions stated: take 3 tablets by mouth once a day for 14 consecutive days. The study was double-blinded with the identification of the group assignment known by the study monitor and the pharmacist who labeled the packages, who did not participate in dispensing the packages. Patients who were discharged before treatment day 14 had the remaining tablets dispensed as to complete the full 14-day treatment course, and were actively evaluated for compliance daily until day 14. All centers followed the same protocol.

At the three hospital sites in Manaus, the treatments were dispensed by the hospital pharmacy at random. Due to logistic difficulties in smaller remote hospitals with limited resources, and the possibility of unmonitored sharing of identical blister packs between patients, a procedure was undertaken to ensure non-sharing within the same site: boxes containing 5-50 treatment packages of the same blinded randomized treatment group were sealed for delivery to remote sites. Each box was delivered by a blinded research assistant directly to the research team at each remote site according to the local demand and enrollment capabilities. A new randomized box was delivered to the remote sites only after dispensing the previous box. The remote sites were not informed that each box contained a single arm, and were instructed to follow the protocol and register in the case report forms the individual package 3-character code dispensed for each patient. This operation procedure introduced a bias in the distribution of drug and placebo between sites. Table S1 details the drug and placebo distribution per site and the randomization scheme used. Figure S1 shows the enrollment over the time of the study. We do not believe the drug and placebo distribution bias impacted the overall results of the study as more proxalutamide was dispensed to the remote hospitals with less resources. 


\section{Supplementary Appendix}

medRxiv preprint doi: https://doi.org/10.1101/2021.06.22.21259318; this version posted June 22, 2021. The copyright holder for this preprint (which was not certified by peer review) is the author/funder, who has granted medRxiv a license to display the preprint in perpetuity.

Table S1. Group Distribution per Site

\begin{tabular}{|c|c|c|c|c|}
\hline \multicolumn{1}{|l|}{ Site } & Randomization & Active & Placebo & Total \\
\hline 1 & Pharmacy & 44 & 144 & 188 \\
\hline 2 & Pharmacy & 28 & 80 & 108 \\
\hline 3 & Pharmacy & 25 & 74 & 99 \\
\hline 4 & Remote/Bulk & 104 & 8 & 112 \\
\hline 5 & Remote/Bulk & 18 & 0 & 18 \\
\hline 6 & Remote/Bulk & 6 & 6 & 12 \\
\hline 7 & Remote/Bulk & 5 & 0 & 103 \\
\hline 8 & Remote/Bulk & 87 & 16 & $\mathbf{6 4 5}$ \\
\hline Total & \multicolumn{3}{|l}{} &
\end{tabular}




\section{Supplementary Appendix}

medRxiv preprint doi: https://doi.org/10.1101/2021.06.22.21259318; this version posted June 22, 2021. The copyright holder for this preprint (which was not certified by peer review) is the author/funder, who has granted medRxiv a license to display the preprint in perpetuity.

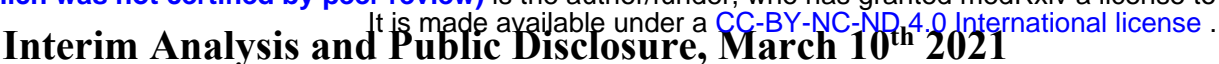

An interim analysis was planned per protocol at 50\% recruitment of the target sample size. Owing to the surge in cases experienced during the trial, however, patient recruitment was rapid and exceeded $50 \%$ before the 28 -day safety assessment. Additionally, when 50\% recruitment goal was achieved (Feb 14) no endpoint data was available. Accordingly, the interim analysis was performed later, in March. The preliminary results were presented to the public on March 10, 2021, in accordance with Brazilian National Research Ethics Committee guidance (National Health Council Resolution Number 466, III.2.m). At the time of the interim analysis, the majority of patients, 99\%, had been randomized; only 9 additional patients were randomized after the event. Figure S1 details the number of patients randomized to study before and after March 10th. It is noteworthy, that only 55 of the 645 patients had yet to complete the 14-day course of study intervention at the time of the public disclosure. As such, we do not believe the disclosure impacted recruitment, data collection, or interpretation of results.

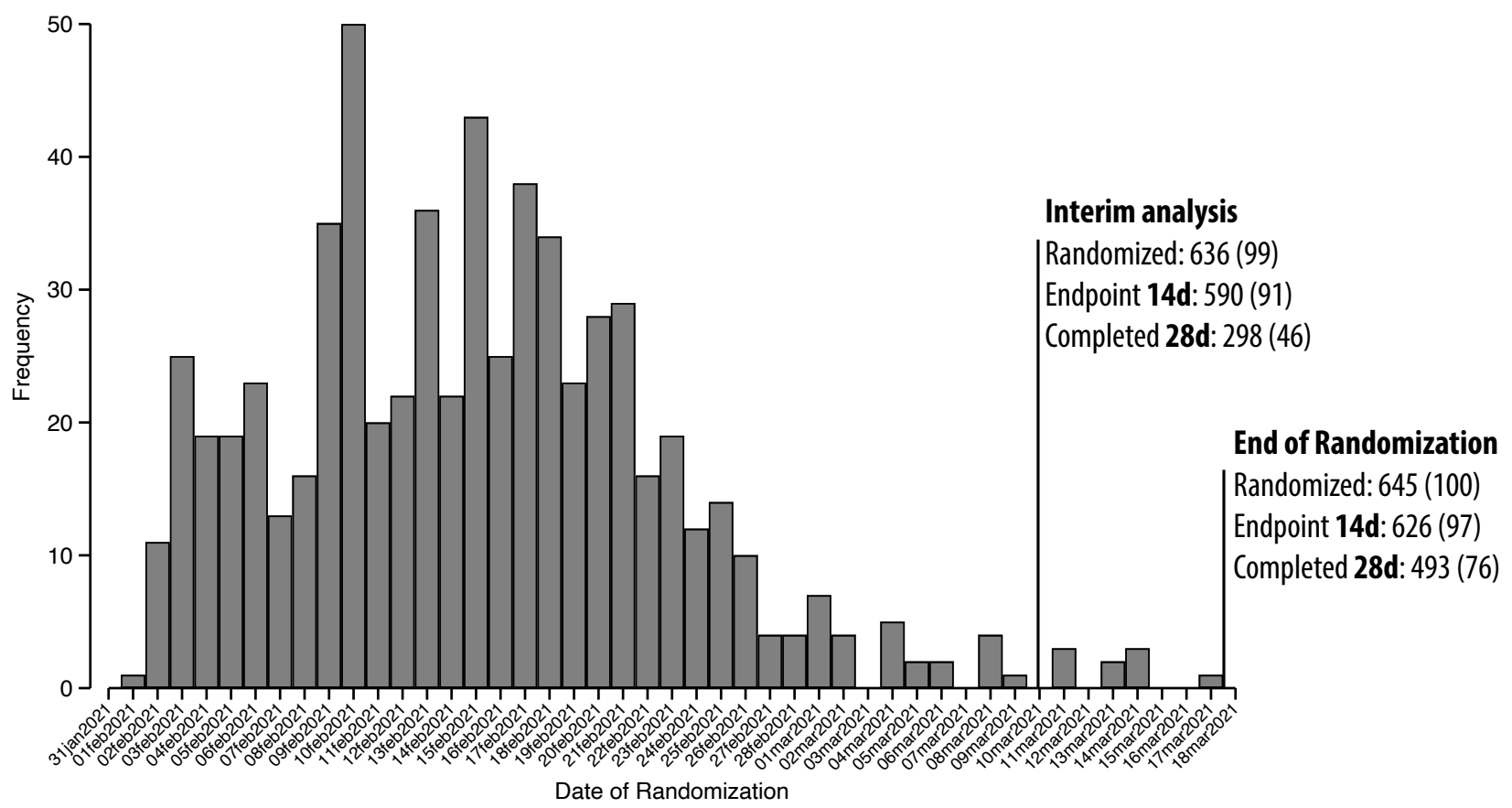

Figure S1. Randomization/recruitment timeline 


\section{Supplementary Appendix}

medRxiv preprint doi: https://doi.org/10.1101/2021.06.22.21259318; this version posted June 22, 2021. The copyright holder for this preprint (which was not certified by peer review) is the author/funder, who has granted medRxiv a license to display the preprint in perpetuity. Dosage Administration and Compliance Procedures

Proxalutamide $300 \mathrm{mg}$ ( 3 x $100 \mathrm{mg}$ tablets) or matching placebo was taken orally once daily with or without food, therapy was initiated soon after randomization. Treatment compliance was monitored and recorded while the patient was hospitalized. An accurate and current accounting of the dispensing of the study drug for each subject was maintained on an ongoing basis by the Investigator or delegated personnel. The number of study drug tablets dispensed to the subject was recorded on the Investigational Product Accountability Log. Patients who were discharged before treatment day 14 had the remaining tablets dispensed as to complete the full 14-day treatment course and were actively evaluated for compliance daily until day 14 . All centers followed the same protocol.

\section{Baseline COVID-19 8-point Ordinal Scale}

The protocol was amended before initiation of the trial because of prevailing disease in the participating hospitals. In the original protocol, the inclusion was limited to COVID-19 8-point ordinal scale scores 3, 4, and 5, i.e., did not include patients requiring non-invasive ventilation or high flow oxygen devices.

Prior to the start of the trial, Brazil, and particularly the state of Amazonas, experienced a surge in COVID-19 resulting in an increase in severity of cases. The majority of hospitalized patients on the days preceding the trial were on high flow oxygen devices (COVID-19 8-point ordinal scale score 6). As such, the decision was made to include score 6 on the day of the initiation of recruitment. All patients, including COVID-19 8-point ordinal scale score 6, were randomized in the same 1:1 ratio as indicated in the Protocol.

We did not perform randomization stratified per site as a result of batch delivery of drugs or placebo (described above). This led to an unbalance between study arms within hospital sites. In three small hospital centers the randomization strategy had to be modified due to: 1) logistic difficulties in taking the drugs to these remote hospitals and 2) limited financial resources. This was done to avoid unblinding and unmonitored sharing of blister packs among hospitals and patients. We are aware that these changes in the randomization scheme increased the risk of bias in the randomization procedure. However, in the 3 sites located in the large urban city of Manaus with higher hospital certification standards, where randomization could be done as originally planned, a lower mortality rate in both arms was observed, as well as a lower mortality risk ratio (Table S4). 


\section{Supplementary Appendix}

medRxiv preprint doi: https://doi.org/10.1101/2021.06.22.21259318; this version posted June 22, 2021. The copyright holder for this preprint (which was not certified by peer review) is the author/funder, who has granted medRxiv a license to display the preprint in perpetuity.

Table S2. Coronavirus disease 2019 8-point ordinal scale scores distribution and

outcomes by baseline scores

\begin{tabular}{|c|c|c|c|c|c|c|}
\hline \multirow{2}{*}{$\begin{array}{l}\text { Characteristic } \\
\text { Treatment Group }\end{array}$} & \multicolumn{3}{|c|}{ BASELINE SCORES 3-5 } & \multicolumn{3}{|c|}{ BASELINE SCORE 6} \\
\hline & $\begin{array}{l}\text { Proxalutamide } \\
\qquad \mathrm{N}=100\end{array}$ & $\begin{array}{l}\text { Placebo } \\
\mathrm{N}=116\end{array}$ & $\begin{array}{c}\text { Risk ratio } \\
(95 \% \mathrm{Cl})\end{array}$ & $\begin{array}{l}\text { Proxalutamide } \\
\mathrm{N}=217\end{array}$ & $\begin{array}{l}\text { Placebo } \\
\mathrm{N}=212\end{array}$ & $\begin{array}{c}\text { Risk ratio } \\
(95 \% \mathrm{Cl})\end{array}$ \\
\hline Females, no. & 52 & 46 & - & 81 & 100 & - \\
\hline Males, no. & 48 & 70 & - & 136 & 112 & - \\
\hline Recovery over 14 days- $n$ (\%) & $89(89.0 \%)$ & $62(53.4 \%)$ & $\begin{array}{c}1.67 \\
(1.39-2.00)\end{array}$ & 169 (77.9\%) & 55 (25.9\%) & $\begin{array}{c}3.00 \\
(2.37-3.80)\end{array}$ \\
\hline Females & 45 (86.5\%) & $22(47.8 \%)$ & $\begin{array}{c}1.81 \\
(1.32-2.49)\end{array}$ & $64(79.0 \%)$ & $29(29.0 \%)$ & $\begin{array}{c}2.72 \\
(1.97-3.78)\end{array}$ \\
\hline Males & $44(91.7 \%)$ & 40 (57.1\%) & $\begin{array}{c}1.60 \\
(1.29-2.00)\end{array}$ & $105(77.2 \%)$ & $26(23.2 \%)$ & $\begin{array}{c}3.33 \\
(2.35-4.71)\end{array}$ \\
\hline Mortality over 28 days- $n$ (\%) & $5(5.0 \%)$ & $39(33.6 \%)$ & $\begin{array}{c}0.15 \\
(0.06-0.36)\end{array}$ & $30(13.8 \%)$ & $123(58.0 \%)$ & $\begin{array}{c}0.24 \\
(0.17-0.34)\end{array}$ \\
\hline Females & $1(1.9 \%)$ & $16(34.8 \%)$ & $\begin{array}{c}0.06 \\
(0.01-0.40)\end{array}$ & $11(13.6 \%)$ & $55(55.0 \%)$ & $\begin{array}{c}0.25 \\
(0.14-0.44)\end{array}$ \\
\hline Males & $4(8.3 \%)$ & $23(32.9 \%)$ & $\begin{array}{c}0.25 \\
(0.09-0.69)\end{array}$ & $19(14.0 \%)$ & $68(60.7 \%)$ & $\begin{array}{c}0.23 \\
(0.14-0.36)\end{array}$ \\
\hline $\begin{array}{l}\text { Hazard ratio for death over } 28 \\
\text { days }(95 \% \mathrm{Cl})\end{array}$ & \multicolumn{3}{|c|}{$0.13(0.05-0.33)$} & \multicolumn{3}{|c|}{$0.16(0.11-0.25)$} \\
\hline Recovery over $\mathbf{2 8}$ days- $\mathrm{n}(\%)$ & $93(93.0 \%)$ & $77(66.4 \%)$ & $\begin{array}{c}1.40 \\
(1.22-1.61)\end{array}$ & $178(82.0 \%)$ & 78 (36.8\%) & $\begin{array}{c}2.23 \\
(1.85-2.68)\end{array}$ \\
\hline Females & $50(96.2 \%)$ & $30(65.2 \%)$ & $\begin{array}{c}1.47 \\
(1.19-1.83)\end{array}$ & $67(82.7 \%)$ & $41(41.0 \%)$ & $\begin{array}{c}2.02 \\
(1.56-2.60)\end{array}$ \\
\hline Males & $43(89.6 \%)$ & $47(67.1 \%)$ & $\begin{array}{c}1.33 \\
(1.10-1.61)\end{array}$ & $111(81.6 \%)$ & $37(33.0 \%)$ & $\begin{array}{c}2.47 \\
(1.88-3.25)\end{array}$ \\
\hline $\begin{array}{l}\text { Median hospitalization days } \\
\text { (IQR) }\end{array}$ & $7(5-10.2)$ & $11(8-16)$ & - & $9(6-13)$ & $12(8-19)$ & - \\
\hline $\begin{array}{l}\text { Post-randomization time to } \\
\text { recovery, Median days (IQR) }\end{array}$ & $4(3-6)$ & $9(5-13)$ & - & $5(4-8)$ & $12(7-17)$ & - \\
\hline Day 14 Scores - median (IQR) & $1(1-1)$ & $2(2-8)$ & - & $1(1-2)$ & $7(2-8)$ & - \\
\hline $\begin{array}{l}\text { 1. Not hospitalized, no } \\
\text { limitations on activities -no.(\%) }\end{array}$ & $78(78.0 \%)$ & $24(20.7 \%)$ & - & $136(62.7 \%)$ & $8(3.8 \%)$ & - \\
\hline $\begin{array}{l}\text { 2. Not hospitalized, limitation } \\
\text { on activities - no. (\%) }\end{array}$ & $11(11.0 \%)$ & $38(32.8 \%)$ & - & $33(15.2 \%)$ & $47(22.2 \%)$ & - \\
\hline $\begin{array}{l}\text { 3. Hospitalized, not requiring } \\
\text { supplemental oxygen - no } \\
\text { longer requires ongoing } \\
\text { medical care - no. (\%) }\end{array}$ & $1(1.0 \%)$ & $5(4.3 \%)$ & - & $2(0.9 \%)$ & $4(1.9 \%)$ & - \\
\hline $\begin{array}{l}\text { 4. Hospitalized, not requiring } \\
\text { supplemental oxygen, requiring } \\
\text { ongoing medical care - no. (\%) }\end{array}$ & $4(4.0 \%)$ & $5(4.3 \%)$ & - & $7(3.2 \%)$ & $11(5.2 \%)$ & - \\
\hline $\begin{array}{l}\text { 5. Hospitalized, requiring } \\
\text { supplemental oxygen - no. (\%) }\end{array}$ & $2(2.0 \%)$ & $4(3.5 \%)$ & - & $9(4.1 \%)$ & $9(4.2 \%)$ & - \\
\hline $\begin{array}{l}\text { 6. Hospitalized, receiving non- } \\
\text { invasive ventilation or high flow } \\
\text { oxygen devices - no. (\%) }\end{array}$ & $0(0.0 \%)$ & $1(0.9 \%)$ & - & $3(1.4 \%)$ & $5(2.4 \%)$ & - \\
\hline $\begin{array}{l}\text { 7. Hospitalized, on invasive } \\
\text { mechanical ventilation }- \text { no. (\%) }\end{array}$ & $0(0.0 \%)$ & $7(6.0 \%)$ & - & $4(1.8 \%)$ & $30(14.2 \%)$ & - \\
\hline 8. Death - no. (\%) & $4(4.0 \%)$ & $32(27.6 \%)$ & - & $23(10.6 \%)$ & $98(46.2 \%)$ & - \\
\hline
\end{tabular}




\section{Supplementary Appendix}

medRxiv preprint doi: https://doi.org/10.1101/2021.06.22.21259318; this version posted June 22, 2021. The copyright holder for this preprint (which was not certified by peer review) is the author/funder, who has granted medRxiv a license to display the preprint in perpetuity.

Table S3. Recovery (coronavirus disease 20198 -point ordinal scale scores 1 or 2, alive

\section{hospital discharge) over 14- and 28-days post-randomization stratified by city}

\begin{tabular}{|c|c|c|c|}
\hline Characteristic & Proxalutamide & Placebo & Risk ratio $(95 \% \mathrm{Cl})$ \\
\hline Recovery over 14 days- no. (\%) & $258(81.4)$ & $117(35.7)$ & $2.28(1.95-2.66[P<0.001])$ \\
\hline \multicolumn{4}{|l|}{ City } \\
\hline Manaus, Amazonas & $85(87.6)$ & 107 (35.9) & $2.44(2.06-2.89)$ \\
\hline Manacapuru, Amazonas & $18(100.0)$ & - & - \\
\hline Manicore, Amazonas & $5(100.0)$ & - & - \\
\hline Maues, Amazonas & $4(66.7)$ & $1(16.7)$ & $4.00(0.61-26.1)$ \\
\hline Itacoatiara, Amazonas & $77(74.0)$ & $4(50.0)$ & $1.48(0.73-2.99)$ \\
\hline Parintins. Amazonas & $69(79.3)$ & $5(31.3)$ & $2.54(1.22-5.29)$ \\
\hline Recovery over 28 days- no. (\%) & $35(11.0 \%)$ & $162(49.4 \%)$ & $0.22(0.16-0.31)$ \\
\hline \multicolumn{4}{|l|}{ City } \\
\hline Manaus, Amazonas & $85(87.6)$ & 107 (35.9) & $2.44(2.06-2.89)$ \\
\hline Manacapuru, Amazonas & $18(100.0)$ & - & - \\
\hline Manicore, Amazonas & $5(100.0)$ & - & - \\
\hline Maues, Amazonas & $4(66.7)$ & $1(16.7)$ & $4.00(0.61-26.1)$ \\
\hline Itacoatiara, Amazonas & $77(74.0)$ & $4(50.0)$ & $1.48(0.73-2.99)$ \\
\hline Parintins. Amazonas & $69(79.3)$ & $5(31.3)$ & $2.54(1.22-5.29)$ \\
\hline
\end{tabular}




\section{Supplementary Appendix}

medRxiv preprint doi: https://doi.org/10.1101/2021.06.22.21259318; this version posted June 22, 2021. The copyright holder for this preprint (which was not certified by peer review) is the author/funder, who has granted medRxiv a license to display the preprint in perpetuity.

Table S4. All-cause mortality over 28 days post-randomization stratified by city

\begin{tabular}{|l|c|c|c|}
\hline Characteristic & Proxalutamide & Placebo & Risk ratio (95\% CI) \\
\hline 28-day all-cause mortality- no. (\%) & $35(11.0)$ & $162(49.4)$ & $0.22(0.16-0.31[\mathrm{P}<0.001])$ \\
\hline City & & & \\
\hline Manaus, Amazonas & $6(6.19)$ & $145(48.7)$ & $0.13(0.06-0.28)$ \\
\hline Manacapuru, Amazonas & $0(0.0)$ & - & - \\
\hline Manicore, Amazonas & $0(0.0)$ & - & - \\
\hline Maues, Amazonas & $2(33.3)$ & $5(83.3)$ & $0.40(0.12-1.31)$ \\
\hline Itacoatiara, Amazonas & $14(13.5)$ & $4(50.0)$ & $0.27(0.12-0.63)$ \\
\hline Parintins. Amazonas & $13(14.9)$ & $8(50.0)$ & $0.30(0.15-0.60)$ \\
\hline
\end{tabular}




\section{Supplementary Appendix}

medRxiv preprint doi: https://doi.org/10.1101/2021.06.22.21259318; this version posted June 22, 2021. The copyright holder for this preprint (which was not certified by peer review) is the author/funder, who has granted medRxiv a license to display the preprint in perpetuity. It is made available under a CC-BY-NC-ND 4.0 International license.
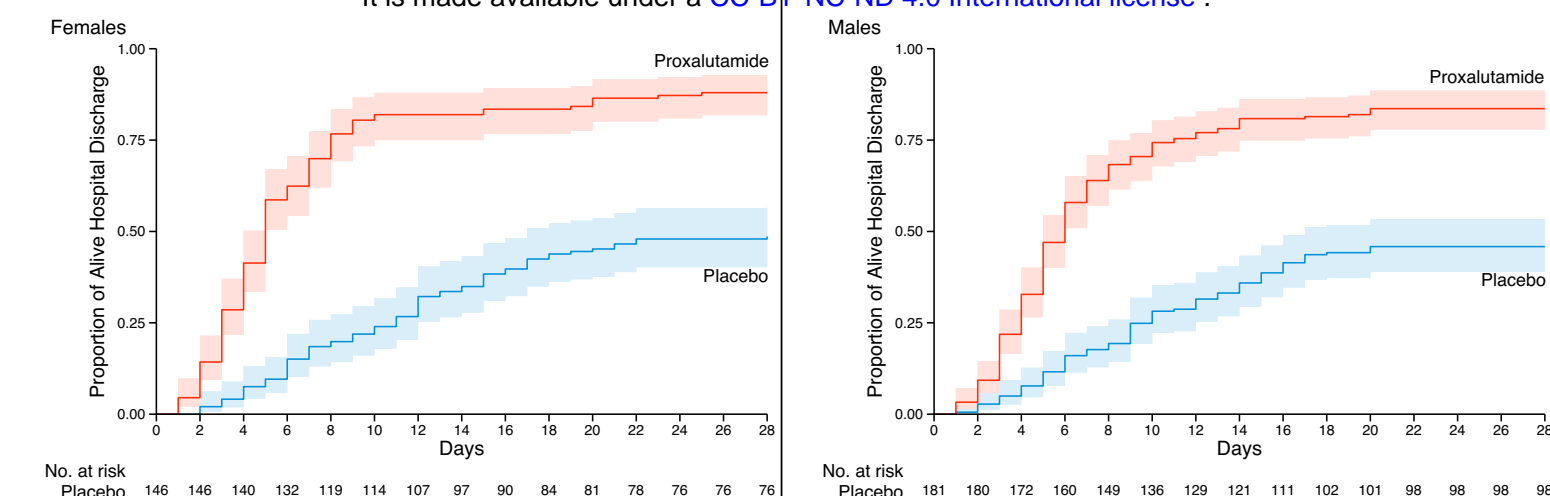

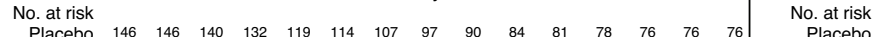

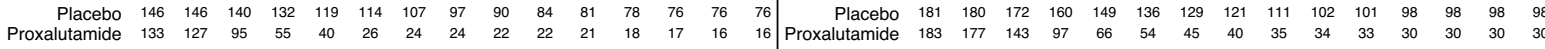

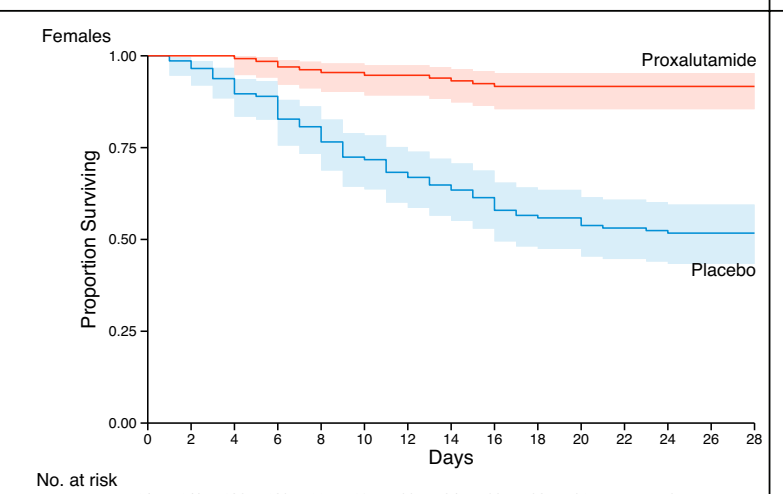

No. at risk

Males ${ }^{1.00}$

\begin{tabular}{llllllllllllllll} 
Proxalutamide & 132 & 132 & 132 & 130 & 127 & 126 & 125 & 124 & 122 & 121 & 121 & 121 & 121 & 121 & 121 \\
\hline
\end{tabular}

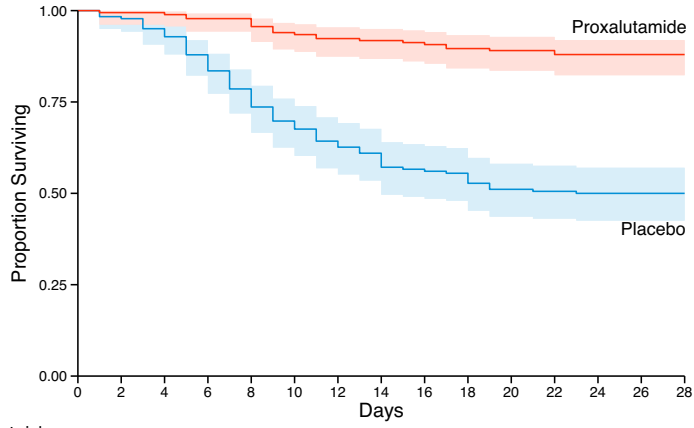

$\begin{array}{llllllllllllllll}\text {. at risk } & 182 & 179 & 173 & 160 & 143 & 127 & 117 & 111 & 103 & 101 & 93 & 91 & 90 & 90 & 90\end{array}$

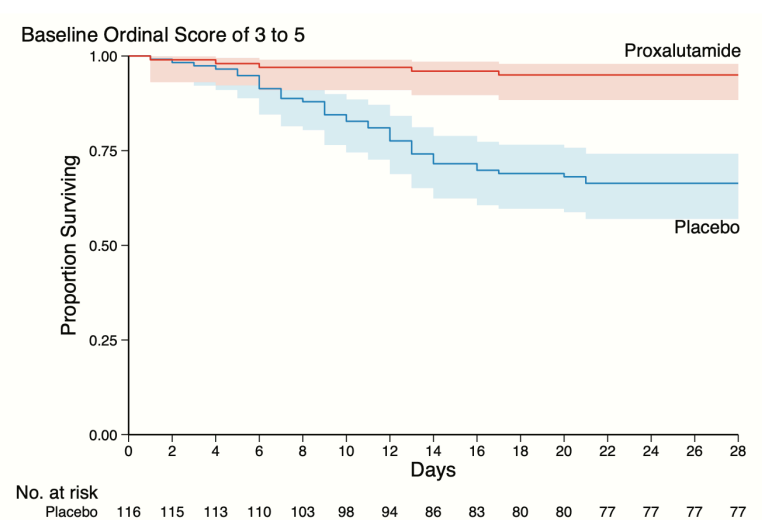

Baseline Ordinal Score of 3 to 5

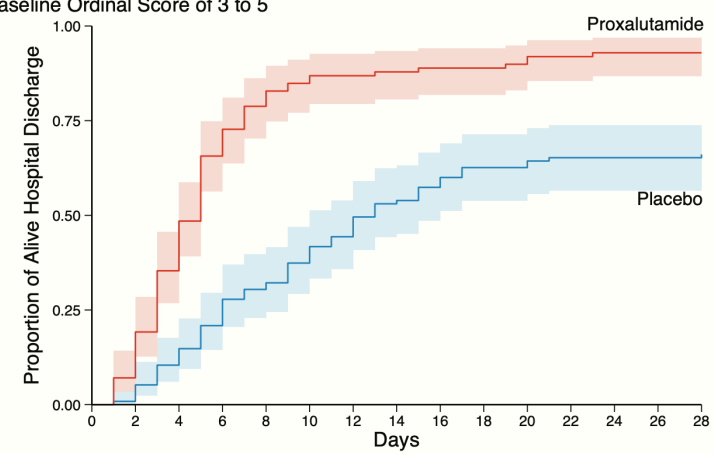

$\begin{array}{cccccccccccccccc}\text { No. at risk } & 116 & 115 & 113 & 110 & 103 & 98 & 94 & 86 & 83 & 80 & 80 & 77 & 77 & 77 & 77 \\ \text { Proxaluatamide } & 100 & 99 & 99 & 98 & 97 & 97 & 97 & 96 & 96 & 95 & 95 & 95 & 95 & 95 & 95\end{array}$

$\begin{array}{rlllllllllllllll}\text { No. at risk } & 115 & 114 & 103 & 91 & 80 & 72 & 64 & 54 & 49 & 43 & 43 & 40 & 40 & 40 & 40 \\ \text { Proxalutamide } & 99 & 92 & 64 & 34 & 21 & 15 & 13 & 12 & 11 & 11 & 10 & 8 & 7 & 7 & 7\end{array}$

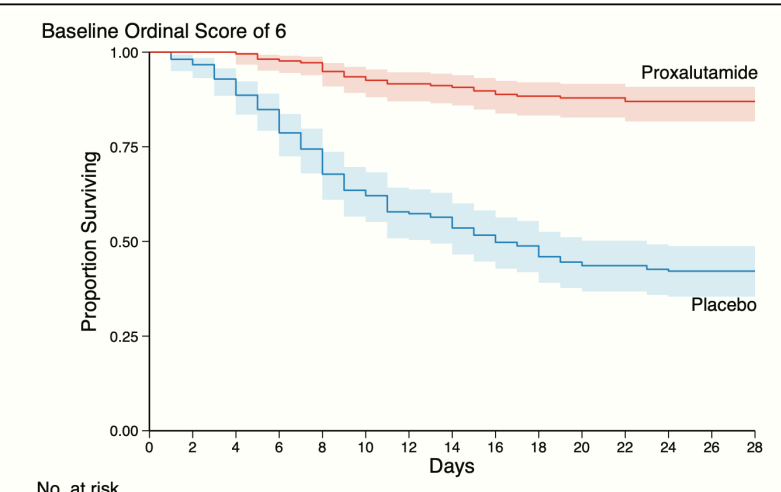

No. at risk

Baseline Ordinal Score of 6

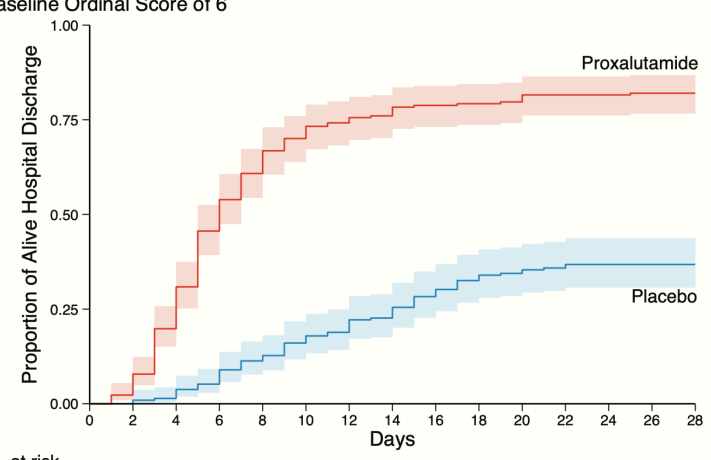

No. at risk

$\begin{array}{cccccccccccccccc}\text { No. at risk } & 212 & 212 & 209 & 201 & 188 & 178 & 172 & 164 & 152 & 143 & 139 & 136 & 134 & 134 & 134 \\ \text { Placebo } & 212 & 214 \\ \text { Proxalutamide } & 217 & 212 & 174 & 118 & 85 & 65 & 56 & 52 & 46 & 45 & 44 & 40 & 40 & 39 & 39\end{array}$

\section{Figure S2. Kaplan-Meier estimates from randomization to Day 28.}

Alive Hospital Discharge and Proportion Surviving by sex and baseline ordinal scale. 


\section{Supplementary Appendix}

medRxiv preprint doi: https://doi.org/10.1101/2021.06.22.21259318; this version posted June 22, 2021. The copyright holder for this preprint (which was not certified by peer review) is the author/funder, who has granted medRxiv a license to display the preprint in perpetuity. It is made available under a CC-BY-NC-ND 4.0 International license .
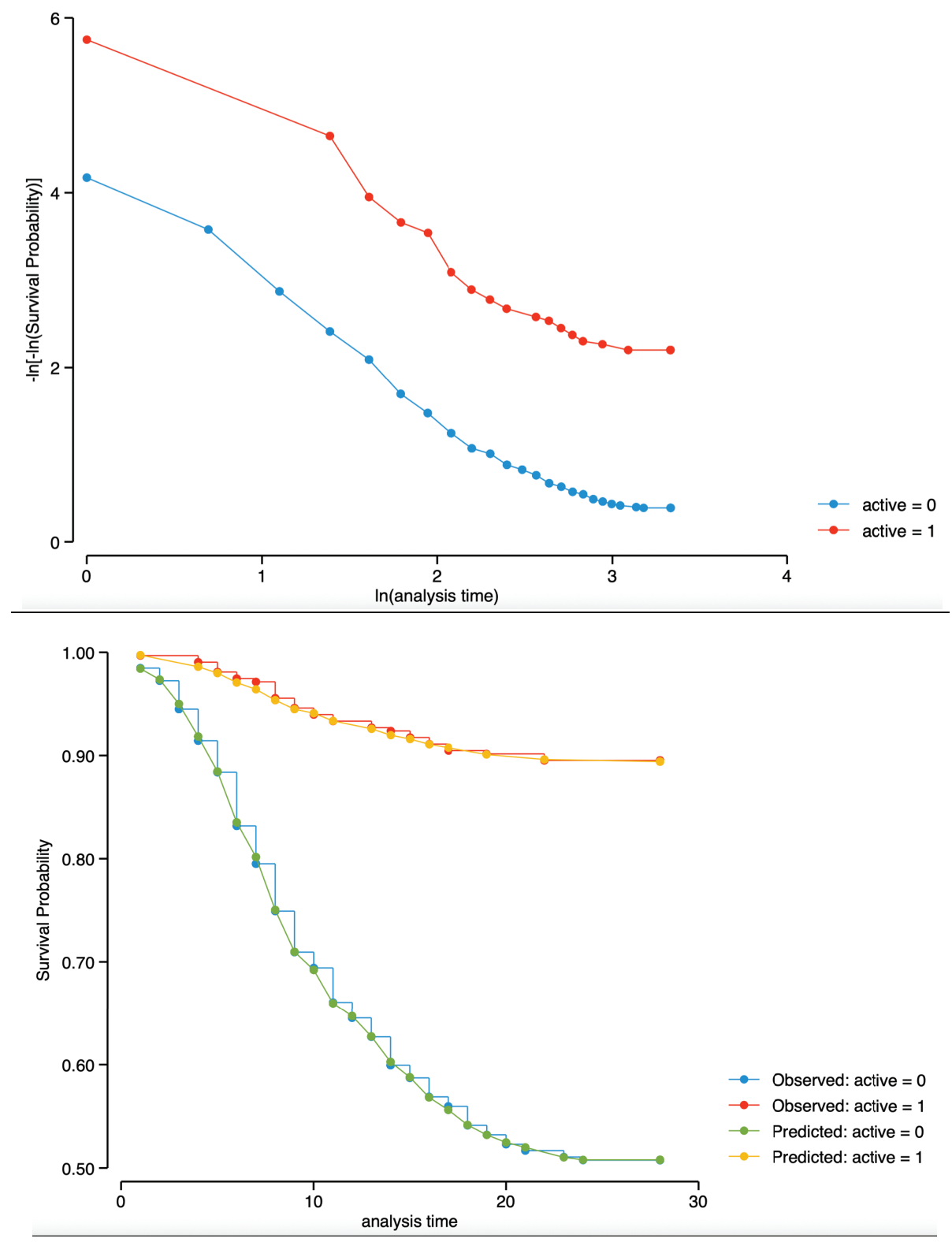

Figure S3. Graphical assessment of proportional-hazards assumption (hazard ratio over 28 days post-randomization).

Top: figure displays lines that are parallel, implying that the proportional-hazards assumption for the therapy groups has not been violated.

Bottom: This is confirmed by Kaplan-Meier versus predicted survival, where the observed values and predicted values are close together for the therapy groups.

Proportional-hazards assumption on the basis of Schoenfeld residuals revealed a global test with $\mathrm{P}$ value $=0.7986$, therefore, we can assume the proportional hazards. 


\section{Supplementary Appendix}

medRxiv preprint doi: https://doi.org/10.1101/2021.06.22.21259318; this version posted June 22, 2021. The copyright holder for this preprint (which was not certified by peer review) is the author/funder, who has granted medRxiv a license to display the preprint in perpetuity. SARS-CoV-2 Lineage Determination

For this post hoc analysis, clinical samples from patients admitted to one of the participating centers testing positive for SARS-CoV-2 in a first RT-qPCR had their samples submitted to a second RT-qPCR performed by BiomeHub (Florianópolis, Santa Catarina, Brazil), using charite-berlin protocol. Only samples with quantification cycle (Cq) below 30 for at least one primer were processed for SARS-CoV-2 genome sequencing by the BiomeHub laboratory.

To perform the SARS-CoV-2 genome sequencing, total RNAs were prepared as in the reference protocol (dx.doi.org/10.17504/protocols.io.befyjbpw) using SuperScript IV (Invitrogen) for cDNA synthesis and Platinum Taq High Fidelity (Invitrogen) for specific viral amplicons. The cDNA obtained were subsequently used for the library preparation with Nextera Flex (Illumina) and quantified with Picogreen and Collibri Library Quantification Kit (Invitrogen). The sequencing was performed on MiSeq 150x150 runs with 500xSARS-CoV-2 coverage (50-100 mil reads/per sample).

The SARS-CoV-2 genome assembly was generated by an in-house pipeline from BiomeHub (Florianópolis, Santa Catarina, Brazil). The remotion of adapters and read trimming in $150 \mathrm{nt}$ were performed with fastqtools.py, followed by the reads mapping to the reference SARS-CoV-2 genome (GenBank accession number NC_045512.2) with Bowtie v2.4.2 (additional parameters: end-to-end and very-sensitive). The mapping coverage and sequencing depth were obtained with samtools v1.11 (minimum base quality per base $(\mathrm{Q}) \geq 30)$. Consensus genome sequences were then generated with bcftools mpileup $(\mathrm{Q} \geq 30$; depth $(\mathrm{d}) \leq 1,000)$ combined with bcftools filter $(\mathrm{DP}>50)$ and bcftools consensus v1.11. Finally, the identification of the SARS-CoV-2 virus lineages was performed by the Pangolin v2.3.8 web server (https://github.com/cov-lineages/pangolin). 


\section{Supplementary Appendix}

medRxiv preprint doi: https://doi.org/10.1101/2021.06.22.21259318; this version posted June 22, 2021. The copyright holder for this preprint (which was not certified by peer review) is the author/funder, who has granted medRxiv a license to display the preprint in perpetuity.

Table S5. Sequencing of $\mathbf{S} A \mathrm{R}^{2}-\mathrm{Co}$ - $V-2$ in 44 Randomly Selected Patients

\begin{tabular}{|c|c|c|}
\hline Sampling Date & City Center & Lineage (PANGOLIN) \\
\hline 18-Feb-2021 & Manaus & P.1 \\
\hline 18-Feb-2021 & Manaus & P.1 \\
\hline 18-Feb-2021 & Manaus & P.1 \\
\hline 18-Feb-2021 & Manaus & P.1 \\
\hline 22-Feb-2021 & Manaus & P.1 \\
\hline 22-Feb-2021 & Manaus & P.1 \\
\hline 22-Feb-2021 & Manaus & P.1 \\
\hline 22-Feb-2021 & Manaus & B.1.1.28 \\
\hline 22-Feb-2021 & Manaus & P.1 \\
\hline 22-Feb-2021 & Manaus & P.1 \\
\hline 22-Feb-2021 & Manaus & P.1 \\
\hline 22-Feb-2021 & Manaus & P.1 \\
\hline 22-Feb-2021 & Manaus & P.1 \\
\hline 22-Feb-2021 & Manaus & P.1 \\
\hline 22-Feb-2021 & Manaus & P.1 \\
\hline 23-Feb-2021 & Manaus & P.1 \\
\hline 23-Feb-2021 & Manaus & P.1 \\
\hline 23-Feb-2021 & Manaus & P.1 \\
\hline 23-Feb-2021 & Manaus & P.1 \\
\hline 23-Feb-2021 & Manaus & P.1 \\
\hline 23-Feb-2021 & Manaus & P.1 \\
\hline 24-Feb-2021 & Manaus & P.1 \\
\hline 24-Feb-2021 & Manaus & P.1 \\
\hline 24-Feb-2021 & Manaus & P.1 \\
\hline 25-Feb-2021 & Manaus & P.1 \\
\hline 25-Feb-2021 & Manaus & P.1 \\
\hline 25-Feb-2021 & Manaus & P.1 \\
\hline 25-Feb-2021 & Manaus & P.1 \\
\hline 25-Feb-2021 & Manaus & P.1 \\
\hline 26-Fev-2021 & Manaus & P.1 \\
\hline 26-Fev-2021 & Manaus & P.1 \\
\hline 01-Mar-2021 & Itacoatiara & P.1 \\
\hline 01-Mar-2021 & Manaus & P.1 \\
\hline 01-Mar-2021 & Manaus & P.1 \\
\hline 01-Mar-2021 & Manaus & P.1 \\
\hline 02-Mar-2021 & Manaus & P.1 \\
\hline 02-Mar-2021 & Manaus & P.1 \\
\hline 03-Mar-2021 & Manaus & P.1 \\
\hline 05-Mar-2021 & Parintins & P.1 \\
\hline 05-Mar-2021 & Manaus & P.1 \\
\hline 08-Mar-2021 & Manaus & P.1 \\
\hline 08-Mar-2021 & Manaus & P.1 \\
\hline 10-Mar-2021 & Manaus & P.1 \\
\hline 10-Mar-2021 & Manaus & P.1 \\
\hline
\end{tabular}




\section{Supplementary Appendix}

medRxiv preprint doi: https://doi.org/10.1101/2021.06.22.21259318; this version posted June 22, 2021. The copyright holder for this preprint (which was not certified by peer review) is the author/funder, who has granted medRxiv a license to display the preprint in perpetuity. It is made available under a CC-BY-NC-ND 4.0 International license.

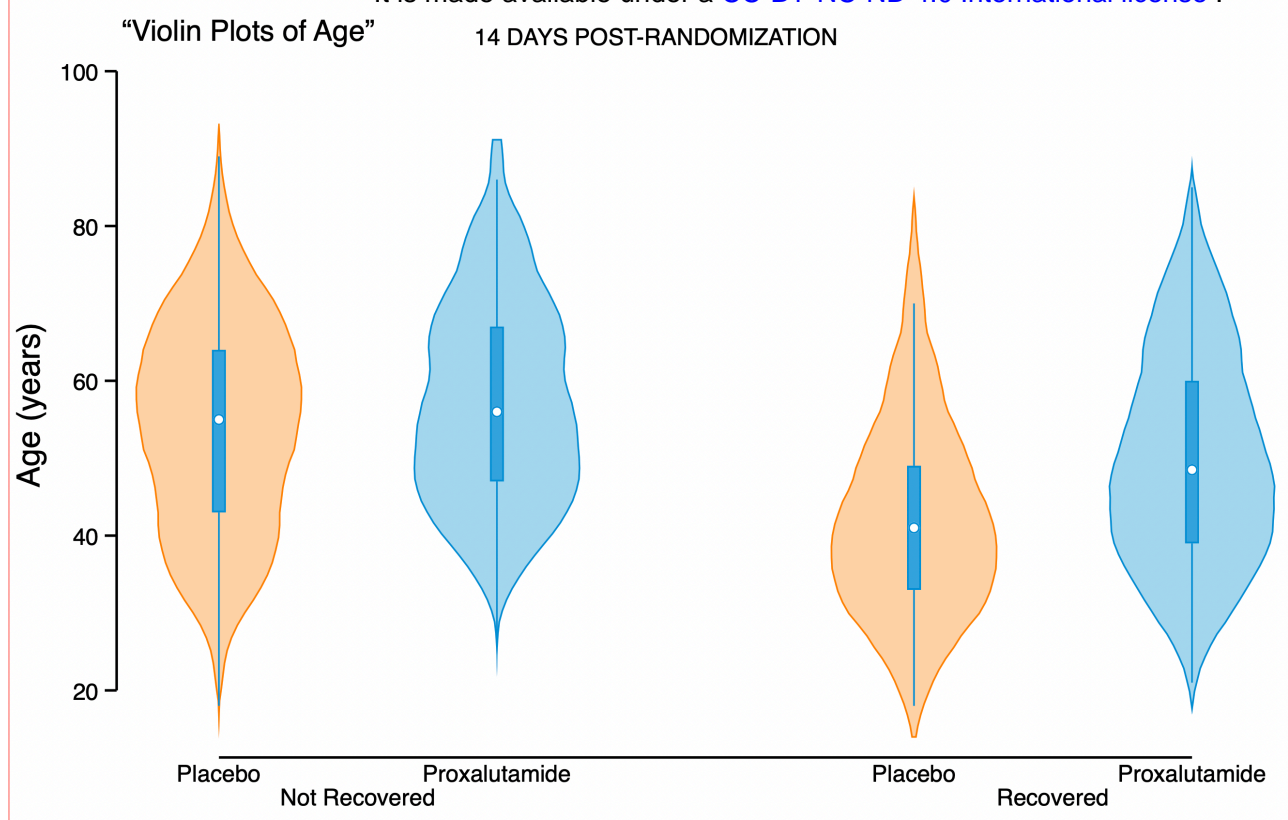

Figure S4. Violin Plots for Age, for alive hospital discharge over the first 14 days postrandomization, per treatment group.

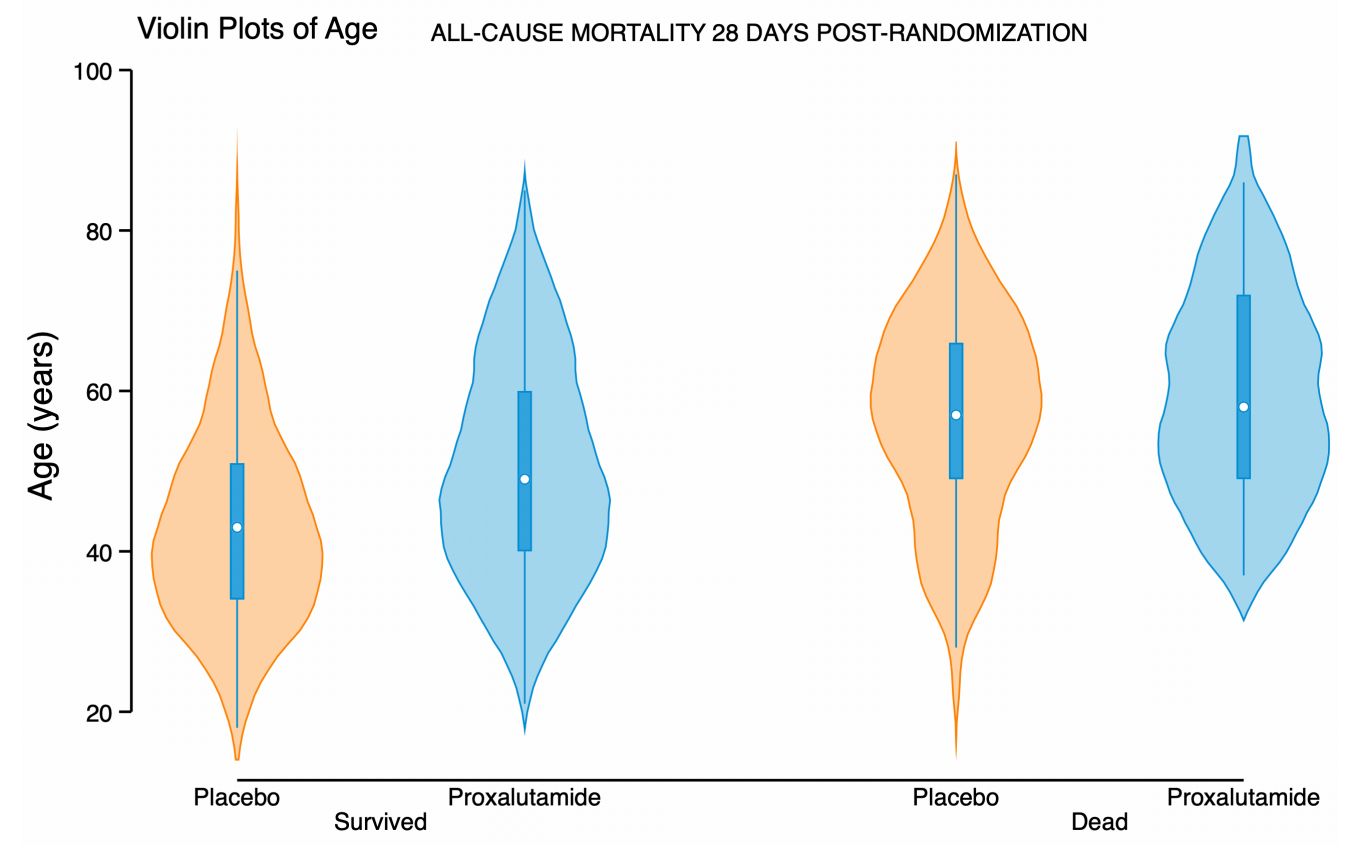

Figure S5. Violin Plots for Age, for all-cause mortality over the 28 days postrandomization, per treatment group. 


\section{Supplementary Appendix}

medRxiv preprint doi: https://doi.org/10.1101/2021.06.22.21259318; this version posted June 22, 2021. The copyright holder for this preprint (which was not certified by peer review) is the author/funder, who has granted medRxiv a license to display the preprint in perpetuity.

Violin Plots of Age

It is made available under a CC-BY-NC-ND 4.0 International license.

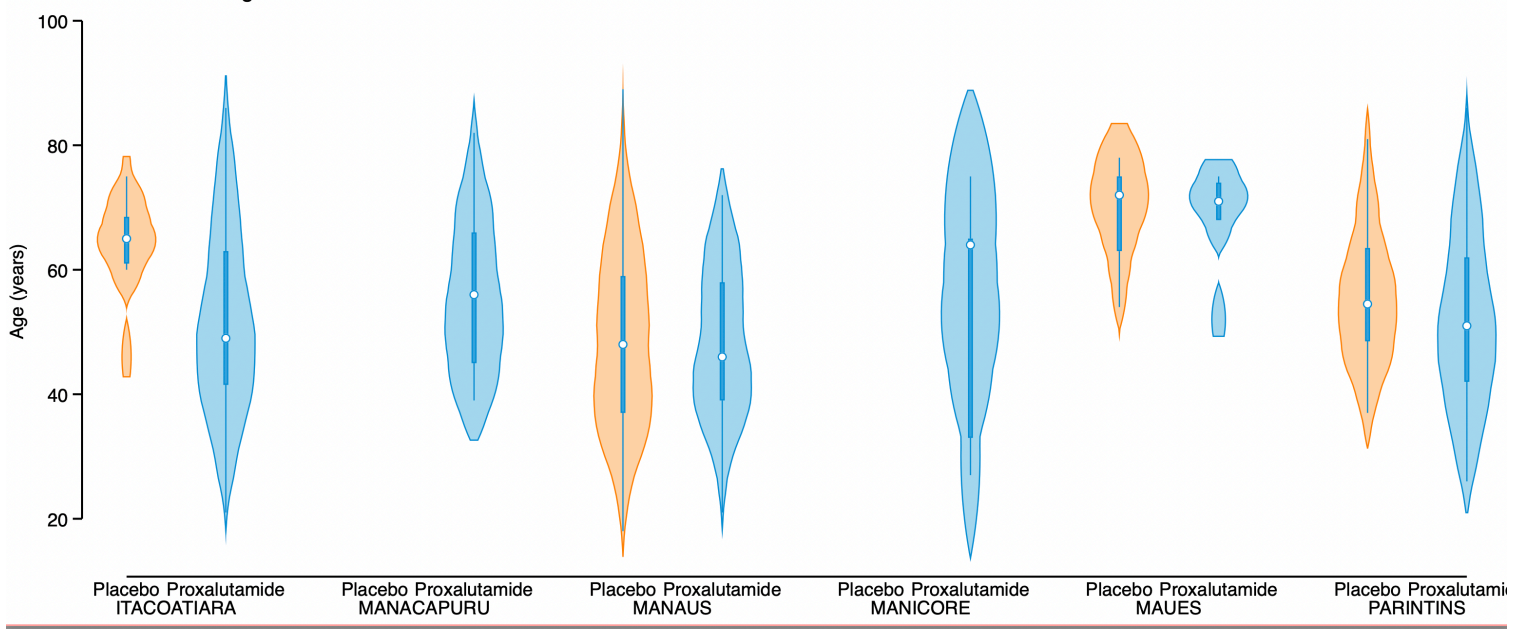

Figure S6. Violin Plots for Age, for cities, per treatment group. 